Review

\title{
Raman Spectroscopy: A Personalized Decision-Making Tool on Clinicians' Hands for In Situ Cancer Diagnosis and Surgery Guidance
}

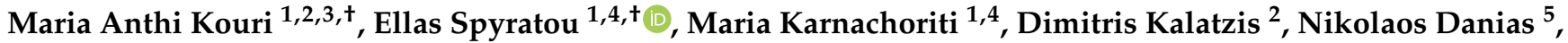 \\ Nikolaos Arkadopoulos ${ }^{5}$, Ioannis Seimenis ${ }^{6}$ (D), Yannis S. Raptis ${ }^{4}$, Athanassios G. Kontos ${ }^{4}$ (D) \\ and Efstathios P. Efstathopoulos $2, *$ (D)
}

Citation: Kouri, M.A.; Spyratou, E.; Karnachoriti, M.; Kalatzis, D.; Danias, N.; Arkadopoulos, N.; Seimenis, I.; Raptis, Y.S.; Kontos, A.G.; Efstathopoulos, E.P. Raman Spectroscopy: A Personalized Decision-Making Tool on Clinicians' Hands for In Situ Cancer Diagnosis and Surgery Guidance. Cancers 2022, 14, 1144. https://doi.org/10.3390/ cancers 14051144

Academic Editor: Fiona Lyng

Received: 30 December 2021

Accepted: 7 February 2022

Published: 23 February 2022

Publisher's Note: MDPI stays neutral with regard to jurisdictional claims in published maps and institutional affiliations.

Copyright: (C) 2022 by the authors. Licensee MDPI, Basel, Switzerland. This article is an open access article distributed under the terms and conditions of the Creative Commons Attribution (CC BY) license (https:// creativecommons.org/licenses/by/ $4.0 /)$.
1 Department of Medicine, Democritus University of Thrace, 68100 Alexandroupolis, Greece; mariakouri90@gmail.com (M.A.K.); spyratouellas@gmail.com (E.S.); mariakarnach@gmail.com (M.K.)

2 2nd Department of Radiology, Medical School, National and Kapodistrian University of Athens, 11527 Athens, Greece; dimitriskalatzis@gmail.com

3 Medical Physics Program, Department of Physics and Applied Physics, Kennedy College of Sciences, University of Massachusetts Lowell, 265 Riverside Street, Lowell, MA 01854, USA

4 Physics Department, School of Applied Mathematical and Physical Sciences, National Technical University of Athens, Iroon Politechniou 9, 15780 Athens, Greece; yraptis@mail.ntua.gr (Y.S.R.); akontos@mail.ntua.gr (A.G.K.)

5 4th Department of Surgery, School of Medicine, Attikon University Hospital, University of Athens, 1 Rimini Street, 12462 Athens, Greece; ndanias@med.uoa.gr (N.D.); narkadopoulos@med.uoa.gr (N.A.)

6 Medical School, National and Kapodistrian University of Athens, 75 Mikras Assias Street, 11527 Athens, Greece; iseimen@med.uoa.gr

* Correspondence: stathise@med.uoa.gr

+ These authors contributed equally to this work.

Simple Summary: Cancer still constitutes one of the main global health challenges. Novel approaches towards understanding the molecular composition of the disease can be employed as adjuvant tools to current oncological applications. Raman spectroscopy has been contemplated and pursued to serve as a noninvasive, real time, in vivo tool which may uncover the molecular basis of cancer and simultaneously offer high specificity, sensitivity, and multiplexing capacity, as well as high spatial and temporal resolution. In this review, the potential impact of Spontaneous Raman spectroscopy in clinical applications related to cancer diagnosis and surgical removal is analyzed. Moreover, the coupling of Raman systems with modern instrumentation and machine learning methods has been explored as a prominent enhancement factor towards a personalized approach promoting objectivity and accuracy in surgical oncology.

\begin{abstract}
Accurate in situ diagnosis and optimal surgical removal of a malignancy constitute key elements in reducing cancer-related morbidity and mortality. In surgical oncology, the accurate discrimination between healthy and cancerous tissues is critical for the postoperative care of the patient. Conventional imaging techniques have attempted to serve as adjuvant tools for in situ biopsy and surgery guidance. However, no single imaging modality has been proven sufficient in terms of specificity, sensitivity, multiplexing capacity, spatial and temporal resolution. Moreover, most techniques are unable to provide information regarding the molecular tissue composition. In this review, we highlight the potential of Raman spectroscopy as a spectroscopic technique with high detection sensitivity and spatial resolution for distinguishing healthy from malignant margins in microscopic scale and in real time. A Raman spectrum constitutes an intrinsic "molecular fingerprint" of the tissue and any biochemical alteration related to inflammatory or cancerous tissue state is reflected on its Raman spectral fingerprint. Nowadays, advanced Raman systems coupled with modern instrumentation devices and machine learning methods are entering the clinical arena as adjunct tools towards personalized and optimized efficacy in surgical oncology.
\end{abstract}


Keywords: Raman spectroscopy; cancer; diagnosis; in situ biopsy; surgical oncology; molecular fingerprint

\section{Introduction}

According to World Health Organization (WHO) [1], in 2020 nearly 10 million cancer deaths have been accounted worldwide while the most common cancer cases pertain breast cancer (2.26 million cases); lung cancer ( 2.21 million cases); and colon and rectum cancer (1.93 million cases) [2-4]. Therefore, the early and accurate diagnosis as well as the precise and adequate surgical removal of a malignancy can lead to the reduction of cancer's high mortality rates [5-7]. Since the differentiation among benign tumors, premalignant, early-stage malignant and healthy tissue is challenging, repeated biopsies are often necessary. Positive predictive values regarding tissue sampling are as low as $22 \%$ for prostate cancer diagnosis, $1.4 \%$ for breast cancer, $18.5 \%$ in lung cancer screenings and $7-23 \%$ for melanoma diagnosis [8-11]. Various conventional imaging techniques have attempted to serve as adjuvant tools for biopsy and surgery guidance. In the field of ionizing radiation, positron emission tomography (PET), computed tomography (CT) and single photon emission computed tomography (SPECT) offer great results, with undisputable drawback relating to the dose deposition to the patient [12-14]. Simultaneously, magnetic resonance imaging (MRI), optical coherence tomography (OCT), white light reflectance (WLR), fluorescence, and high frequency ultrasound by exploiting non-ionizing radiation have proved to be valuable diagnostic tools [15-18]. Nonetheless, currently, no single imaging modality has been proven sufficient in terms of the required standards of specificity, sensitivity, multiplexing capacity, spatial and temporal resolution, and low cost $[19,20]$. Moreover, most techniques are unable to provide information regarding the molecular tissue composition [21,22]. They just confide on visual changes of the tissue structure and thus present lack of specificity $[23,24]$.

Optical vibrational spectroscopic techniques, such as Raman spectroscopy (RS), can depict the gradual changes among malignant and healthy tissue by exploiting the analysis of the characteristic Raman spectrum [24,25]. Raman spectroscopy is a spectroscopic technique offering high detection sensitivity and spatial resolution of a few $\mu \mathrm{m}$. In general, RS provides information of the short-range molecular vibrational level where the Raman bands are characteristic of the molecular bonding in each chemical group. Eventually, the chemical conformation and the environment of the macromolecular level determine the exact frequencies of the Raman bands. Therefore, Raman Scattering can provide exquisite detail of particular sites of interest and of any biochemical alteration related to the inflammatory, or cancer state of tissue. These tissue related details are reflected on the spectral fingerprint [26] since Raman spectrum constitutes an intrinsic "molecular fingerprint" of the sample $[27,28]$. This leads to a treasure of information regarding the vibrational modes related to specific chemical configurations present in tissues, correlated with proteins, lipids, glucose consumption, DNA, RNA, and other biomolecules [29]. Consequently, the entirety of a Raman spectrum can provide the analytic guideline of biological sample's structure, identity, and composition as well as the depiction of macromolecules interactions and composition [27]. Due to that, RS offers high molecular specificity into the characterization of biological tissues ex vivo and in vitro and constitutes an excellent non-invasive detection method of the molecular differences among tumor and healthy tissue [30-32]. Moreover, RS does not require any reagents, labelling or other preparation of the tissue while the use of optical fibers allows the assessment of several anatomical locations in vivo [21,31,33,34].

Vigorous attempts have been made during the last decade towards the clinical implementation of Raman spectroscopy in the hope of addressing the same fundamental issue: the inadequacy of pre- and intraoperative methods with satisfactory and clinically relevant specificity and sensitivity. The most recent studies are aiming into the quadruple of: (1) premalignant lesions detection, (2) detection of cancer in less advanced stages, (3) the reduction 
of unnecessary biopsies, and (4) guided surgery for the entire removal of a malignancy with adequate tumor resection margins [35-38]. According to the literature, in vivo and ex vivo trials which are aiming towards the detection of malignant tissue have accomplished specificities varying between $45-100 \%$ and sensitivities varying between $77-100 \%$ [39-42]. Studies with the goal of pre-malignant lesions detection observed sensitivities ranging among 70-93.5\% and specificities ranging between 63-97.8\% [43]. Even though the numbers presented may not touch perfection, they still constitute a strong argument towards the capability of Raman spectroscopy to enhance current clinical practice.

In this review, we provide an overview of the most prominent Raman spectroscopy applications in biological and clinical research. We highlight the perspective of advanced Raman systems incorporation in clinical praxis as an adjunct tool towards early diagnosis and oncologic surgery guidance. The combination of Raman spectroscopy with modern instrumentation devices, novel techniques, and machine learning methods is presented. This coupling will contribute to overcoming current limitations which have prevented the broad clinical application of Raman spectroscopy so far and will establish RS's potential to be used as a personalized decision-making tool.

\section{Raman Spectra Analysis for Tissue Characterization}

In general, configurations of nearby chemical bonds are characterized by typical vibrational energies. When photons, emitted by a laser light source, are inelastically scattered by these characteristic molecular oscillations, a Raman scattering event takes place. The detection and analysis of the scattered photons offers a spectrum comparted of the so called characteristic Raman peaks. Each individual peak is indicative of a particular vibrational mode related to distinct chemical configurations [22,25]. Various Raman techniques have been developed to cover the distinct requirements of each biomedical sample such as: Spontaneous Raman Spectroscopy (SRS) [27,44,45], Resonance Raman Spectroscopy (RRS)[45], Surface-Enhanced Raman Scattering (SERS) [46-50], and Coherent anti-Stokes Raman scattering (CARS) [51-54] etc. Nevertheless, despite the advancement of these techniques, they still present complexities during experimentation and analysis and thus cannot be yet applied as a simple surgery tool. This review will be concentrated on conventional Spontaneous RS.

Prominent tissue Raman peaks are observed in the fingerprint of $800-1800 \mathrm{~cm}^{-1}$ and the high frequencies $2800-3200 \mathrm{~cm}^{-1}$, spectral regions. A characteristic example of Raman spectra could be this from colorectal tissues by Bergholt et al. They performed discrimination between normal, hyperplastic, adenoma, and adenocarcinoma using nearinfrared Raman spectroscopy [55]. Figure 1 shows the mean of in vivo Raman spectra of normal $(n=1464)$, hyperplastic polyps $(n=118)$, adenoma $(n=184)$, and adenocarcinoma $(n=103)$ acquired from 121 lesions of 50 patients during colorectal endoscopy. The strongest Raman bands are marked upon the spectra and are related to specific vibrations in cellular or extracellular components: $853 \mathrm{~cm}^{-1}(v(C-C)$ proteins $), 1004 \mathrm{~cm}^{-1}(\mathrm{vs}(\mathrm{C}-\mathrm{C})$ ring breathing of phenylalanine), $1078 \mathrm{~cm}^{-1}\left(v(\mathrm{C}-\mathrm{C})\right.$ of lipids), $1265 \mathrm{~cm}^{-1}$ (amide III $v(\mathrm{C}-\mathrm{N})$ and $\delta(\mathrm{N}-$ $\mathrm{H})$ of proteins), $1302 \mathrm{~cm}^{-1}\left(\mathrm{CH}_{2}\right.$ twisting and wagging of lipids), $1445 \mathrm{~cm}^{-1}\left(\delta\left(\mathrm{CH}_{2}\right)\right.$ deformation of proteins and lipids), $1618 \mathrm{~cm}^{-1}\left(v(\mathrm{C}=\mathrm{C})\right.$ of porphyrins), $1655 \mathrm{~cm}^{-1}$ (amide I $v\left(\mathrm{C}=\mathrm{O}\right.$ ) of proteins), $2850 \mathrm{~cm}^{-1}$ and $2885 \mathrm{~cm}^{-1}$ (symmetric and asymmetric $\mathrm{CH}_{2}$ stretching of lipids), $2940 \mathrm{~cm}^{-1}\left(\mathrm{CH}_{3}\right.$ stretching of proteins), $3009 \mathrm{~cm}^{-1}$ (asymmetric $=\mathrm{CH}$ stretching of lipids). Bands above $3200 \mathrm{~cm}^{-1}$ are $\mathrm{OH}$ stretching modes of water. 


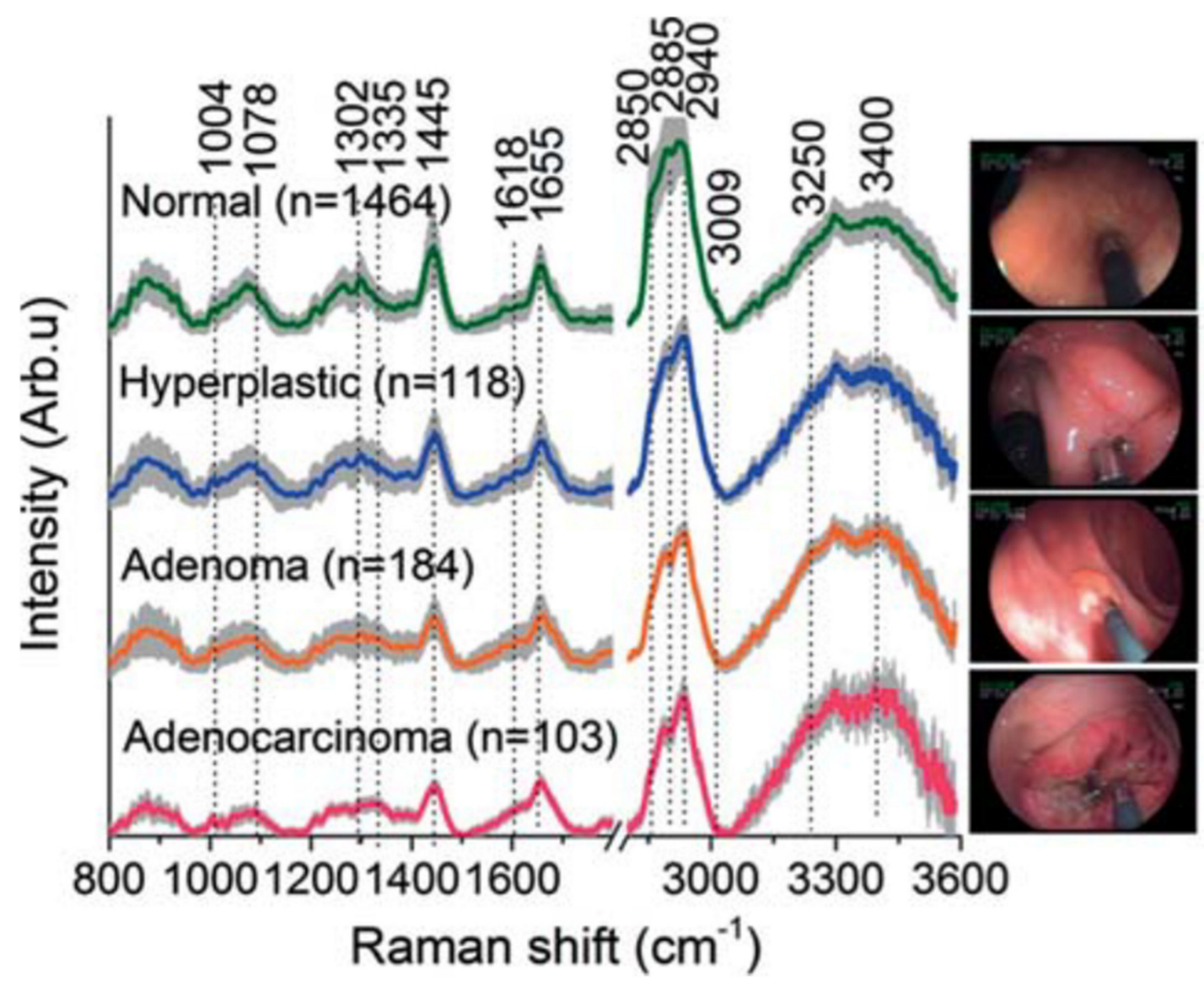

Figure 1. Mean \pm 1 standard deviation (SD) values of in vivo fingerprint (FP) spectra $\left(800-1800 \mathrm{~cm}^{-1}\right)$ and high-wavenumber (HW) Raman spectra $\left(2800-3600 \mathrm{~cm}^{-1}\right)$ of normal $(n=1464)$, hyperplastic polyps $(n=118)$, adenoma $(n=184)$, and adenocarcinoma $(n=103)$ acquired from 121 lesions of 50 patients during colorectal endoscopy. The spectra have been normalized to the integrated area in the FP and HW ranges for comparison purpose. Reused with permission from [55]. Copyright 2015 WILEY-VCH Verlag GmbH \& Co. KGaA, Weinheim, Germany.

\section{Machine Learning and Deep Learning as Tools towards Raman Spectra Analysis}

The analysis of the vast amount of Raman data is a critical barrier which needs to be overcome in order to enable the facilitation of Raman spectroscopy in the clinical routine [56]. However, the evolution of artificial intelligence (AI) provided a boost in realtime Raman data processing. The combination of AI tools with Raman spectroscopy can efficiently lead to adequate discrimination of cancerous tissues [57]. Machine learning (ML) and Deep learning (DL) constitute branches of the broader division of Artificial Intelligence (AI) [58]. Their advanced innovation deservedly classifies them as an excellent candidate for medical applications especially for those dependent on complex, highly versatile genomic procedures such as cancer diagnosis and detection [59-61]. ML or DL could constitute valuable tools in physics applications in medicine such as Raman spectroscopy, where the detection and analysis of various spectral fingerprints is vital [62-64].

Figure 2 is a schematic representation of the workflow of the combination of Raman spectroscopy with machine learning models for tissue discrimination and classification using a multilayer perceptron (MLP). 


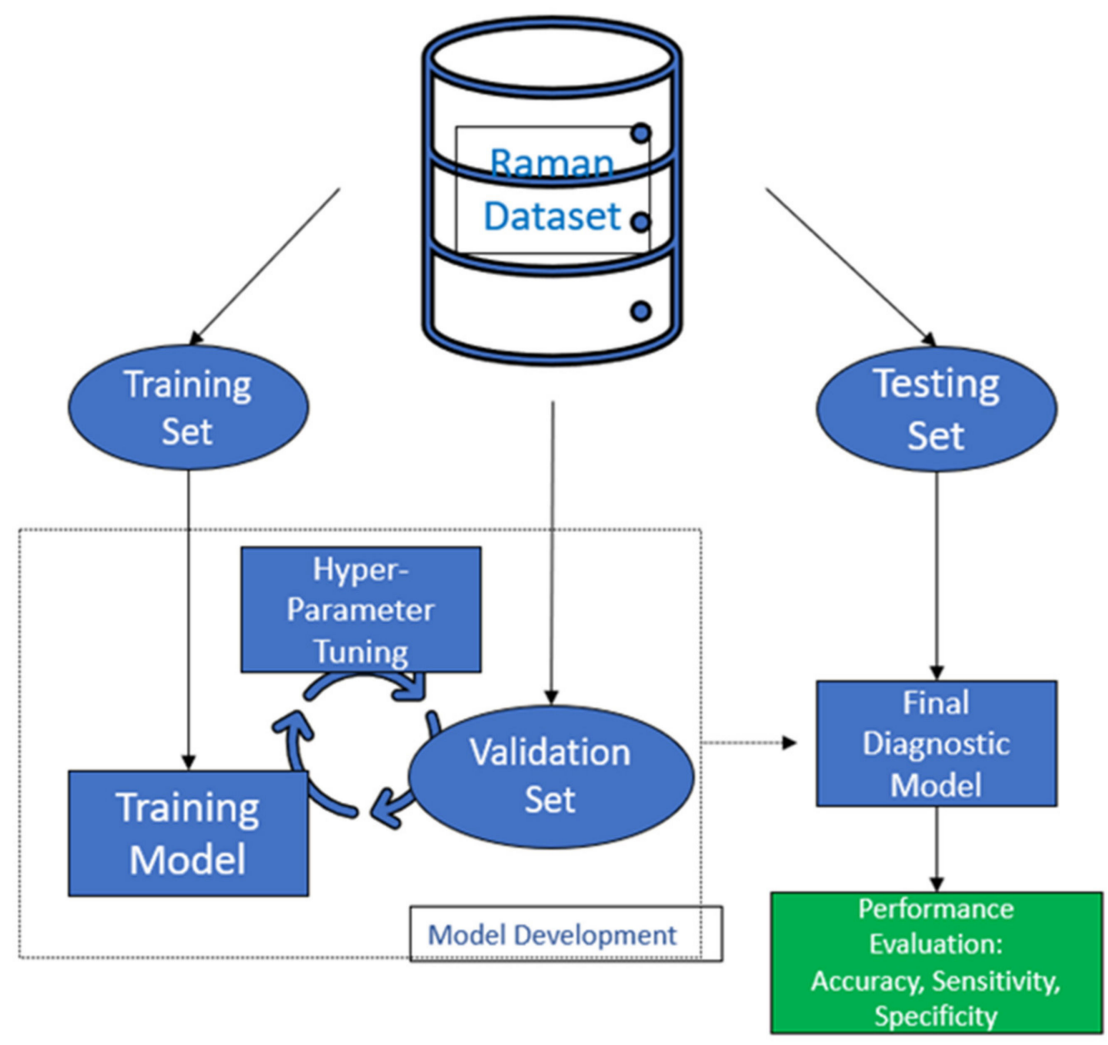

Figure 2. Depicts the basic structure of Machine Learning workflow applied on a Raman Dataset.

In more detail, features extracted from Raman spectra (e.g., representative intensities at certain wavenumbers) and/or from spectral images of biostructures (e.g., pixel intensity patterns) are used as inputs to an MLP. The hidden layers of an MLP will introduce a series of linear and non-linear calculations that will lead to a single output neuron. Each output corresponds to normal or malignant class towards the discrimination between healthy and cancerous tissues. Several machine learning models such as Support Vector Machine (SVM) [65], boosted tress [66], convolutional neural networks (CNNs) [67], and artificial neural networks (ANNs) [68] have been exploited for cancer detection for almost 20 years [69].

Xiaozhou Li et al. focused on the expediency of Raman spectroscopy for colon cancer diagnosis by serum analysis. They observed statistically important spectroscopic differences among cancerous and normal cells for six Raman peaks at 750, 1083, 1165, 1321, 1629, and $1779 \mathrm{~cm}^{-1}$, which indicate nucleic acids, amino acids, and chromophores respectively. The intensity of the peaks in the cancerous cells either increases or decreases reflecting the induced chemical modifications. For example, the decrease of the $1165 \mathrm{~cm}^{-1}$ peak is related to low levels of anti-oxidant $\beta$-carotene in the cancerous cells. They used principal component analysis (PCA) and k nearest neighbor analysis (KNN). They concluded that a number of the PC loading peaks are identified as colon tissue peaks which eventually proved the correlation among the original Raman spectra and the PC loading spectra. Specificity calculated by KNN analysis reached $92.6 \%$ and a diagnostic accuracy of 91\% [70]. The diagnostic models built with the identified Raman bands provided diagnostic accuracy of $93.2 \%$ into identifying colorectal cancer.

Ragini Kothari et al. investigated rapid, quantitative, probabilistic breast tumor assessment with real time error analysis. They observed that often the spectral shifts that were denoted as malignant would constitute false positives due to lack of lipid signals [71]. Stochastic neural networks (NNs) were exploited to estimate the Bayesian probability of a Raman spectrum containing characteristic peaks of cancer using data from the entire spectral bandwidth $\left(600-3000 \mathrm{~cm}^{-1}\right)$, the fingerprint region $\left(600-1800 \mathrm{~cm}^{-1}\right)$, and the 
high wavenumber region (2800-3000 $\mathrm{cm}^{-1}$ ) [68]. Qingbo Li et al. suggested an entropy weighted local-hyperplane k-nearest-neighbor (EWHK) algorithm to determine the Raman spectra in breast cancer by enhancing the classification accuracy [72]. This method led to a positive prediction rate of $95.99 \%$, a negative prediction rate of $83.69 \%$, specificity of $87.77 \%$, accuracy of $92.33 \%$, and sensitivity of $93.81 \%$ [72].

Shaoxin Li et al. used near-infrared Raman spectroscopy and feature selection approaches to detect colorectal cancer tissues. Significant differences were identified between normal and cancerous cells by using ant colony optimization (ACO) and support vector machine (SVM) algorithms for five Raman bands related to proteins, nucleic acids, and lipids of tissues in the areas of 815-830, 935-945, 1131-1141, 1447-1457, and 1665-1675 $\mathrm{cm}^{-1}$. For example, the $1323 \mathrm{~cm}^{-1}$ band, which is assigned to nucleic acids $\left(\mathrm{CH}_{3} \mathrm{CH}_{2}\right.$ twisting mode), increases in cancer tissues compared to normal ones, reflecting the higher content of nucleic acid in tumor cells. A diagnostic accuracy of $93.2 \%$, a sensitivity of $92.3 \%$, and a specificity of $94.2 \%$ were achieved [73].

Non-linear NNs have been used to predict the Bayesian probability of breast cancer. Nine spectra regions, six in the fingerprint region $\left(600-1800 \mathrm{~cm}^{-1}\right)$ and three in the high wavenumber region (2800-3200 $\mathrm{cm}^{-1}$ ), were identified comparing DNA/RNA, protein, carbohydrate, and lipid cellular components of healthy and cancerous cells [71]. Deep convolution neural networks have been applied to fiber optic Raman spectroscopy systems providing a novel classification method for tongue squamous cell discrimination [74] According to the results, high sensitivity (99.31\%) and specificity (94.44\%) were achieved.

\section{Advanced Raman Systems in Clinical Praxis}

\subsection{Raman Systems for Early Diagnosis}

According to the literature, Raman spectroscopy-based biopsy guidance presents overall specificities and sensitivities between $66-100 \%$ and $73-100 \%$ respectively $[21,24]$. The use of this technique promises a drastic increase in the accuracy of cancer diagnosis and an important reduction in the number of false positive biopsies [31,33,34]. The detector technology improvement, the in vivo fiber-optic probe design and the use of artificial intelligence algorithms as well as the collection of large independent comprehensive datasets obtained in the actual clinical workflow enable the facilitation of Raman-based systems into the routine clinical settings [23].

Fiber-optic probes have enabled the access of Raman spectroscopy in in vivo diagnostic techniques [55]. The ability of fiber probes to be inserted endoscopically, especially in hollow and solid organs, such as the upper gastrointestinal tract, the colorectal, and cervical cancers, or the oral cavity, the bladder, and the lung, enables in vivo measurements and in vivo assessment [55,75-77]. Advanced fiber probes such as probes with plasmonic nanostructures on their distal end surface can provide enhancement of the surface Raman scattering signal [78]. Moreover, fiber probes can overcome the limited penetration depth of laser radiation in tissues due to the high diffusion and scattering of photons. Figure 3 shows a portable Raman imaging system based on SERS fiber-optics probes capable of conducting white light endoscopy [79].

Moreover, novel Raman techniques combined with advanced fiber probes can offer a boost to Raman Spectroscopy's application in clinical praxis. For example, Micro-scale spatially offset Raman spectroscopy with an optical fiber probe (micro-SORS) can collect photons from deeper layers by offsetting the position of the laser excitation beam [80] and by reaching a penetration depth up to $5 \mathrm{~cm}$ [81]. Recently, Zhang et al. combined microSORS with Surface-enhanced Raman spectroscopy (SERS) applied on a tissue phantom of agarose gel and biological tissue of porcine muscle [82]. According to their results, the penetration depth could be improved over $4 \mathrm{~cm}$ in agarose gel and $5 \mathrm{~mm}$ in porcine tissue compared to the $2 \mathrm{~cm}$ depth of agarose gel and the $3 \mathrm{~mm}$ depth in porcine muscle received by SERS measurements. 


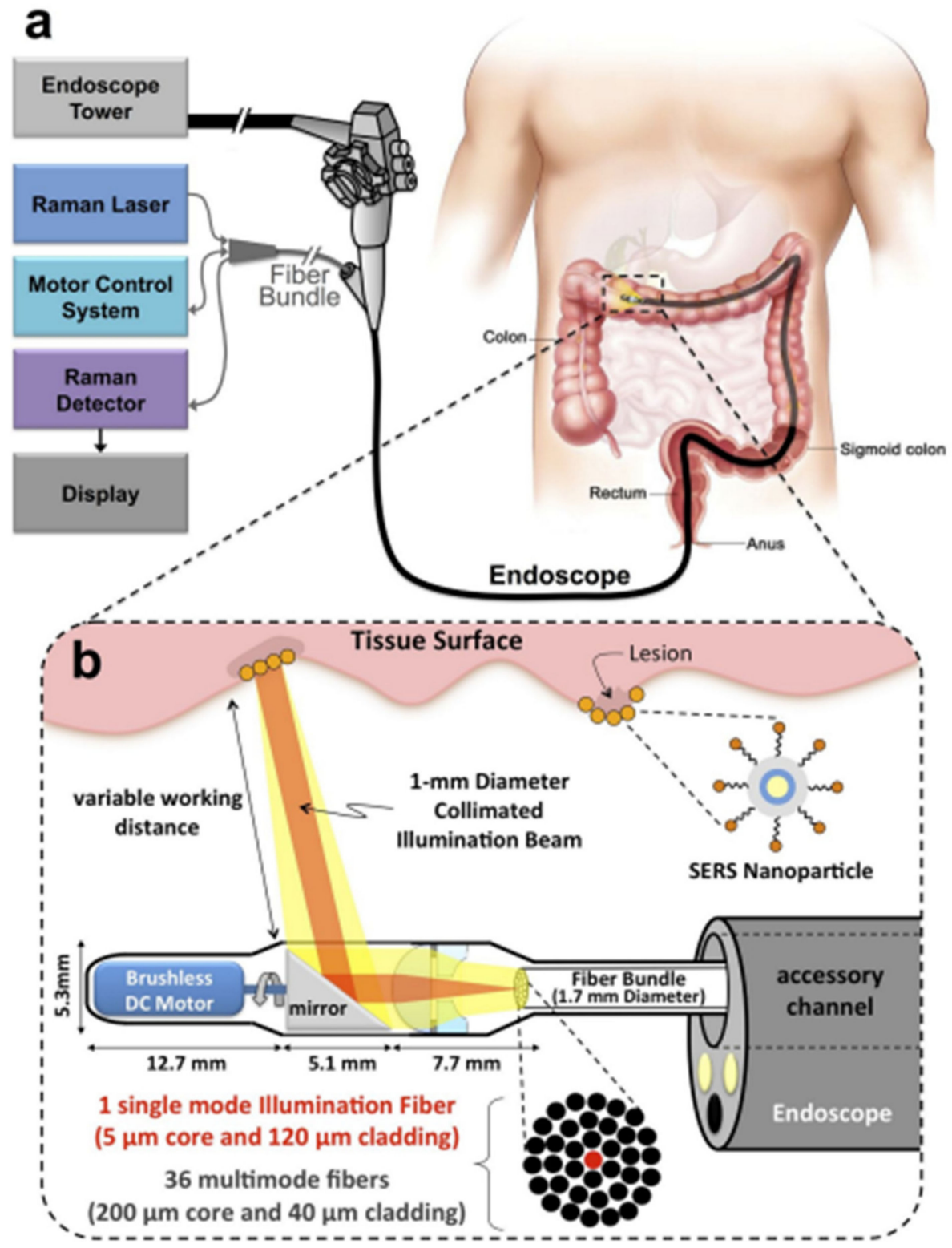

Figure 3. Schematic representation of a Raman system with SERS fiber-optic probe based Raman system which can perform white light endoscopy. (a) The design allows the Raman imaging system to get adapted on a clinical endoscope and scan the lumen as the endoscope is being retracted in the GI tract. (b) An expanded schematic illustration of the distal end of the device. The collimated beam can be swept by a brushless DC motor and its focus can be adjusted by a system of planoconvex and plano-concave lenses [79], https:/ / doi.org/10.1371/journal.pone.0123185, access on 10 January 2022).

Stevens et al. and Wang et al. investigated epithelial tissue associated with dysplasia and developed a Raman probe coupled with a ball lens that could enhance in vivo Raman measurements from gastric premalignant epithelial tissue during endoscopy [83,84]. Due to the use of a ball lens, they managed to decrease the collection depth at $300 \mathrm{~nm}$, which is the relevant depth for the analysis of gastric epithelium [83,84]. Moreover, they exploited a multimodal image-guided Raman technique to achieve real time in vivo cancer detection. Bergholt et al. used this high wavenumber system in combination with a foot pedal control switch and auditory feedback to the gastroenterologist during colonoscopy diagnosis [85]. Another team, Agenant et al., developed a novel Raman probe that could 
take measurements at the depth of 0-200 $\mu \mathrm{m}$ (average urothelium depth), the adequate level for superficial tissue sampling, in order to improve in vivo diagnosis of urothelial carcinoma [86]. This novel probe was comparted of seven collection fibers, one excitation fiber and two component front lens [86]. Figure 4 shows the different geometries of fiber-optics probes used in clinical applications such as endoscopic probes without any focusing optics, confocal endoscopic probes, and fiber probes for side-viewing [87].

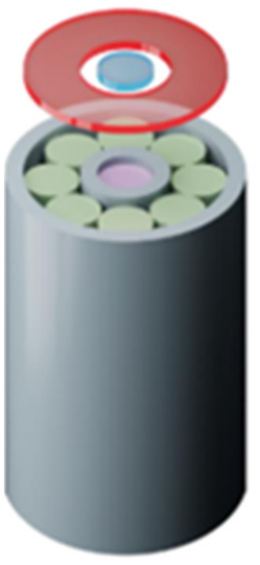

(a)

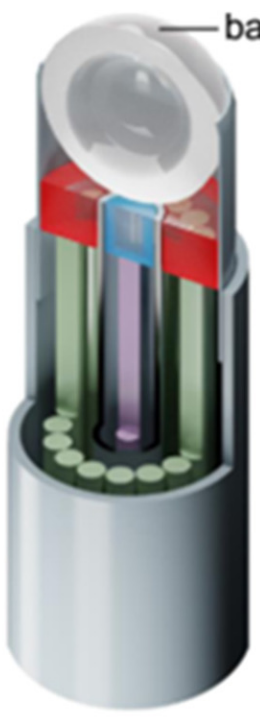

(b)

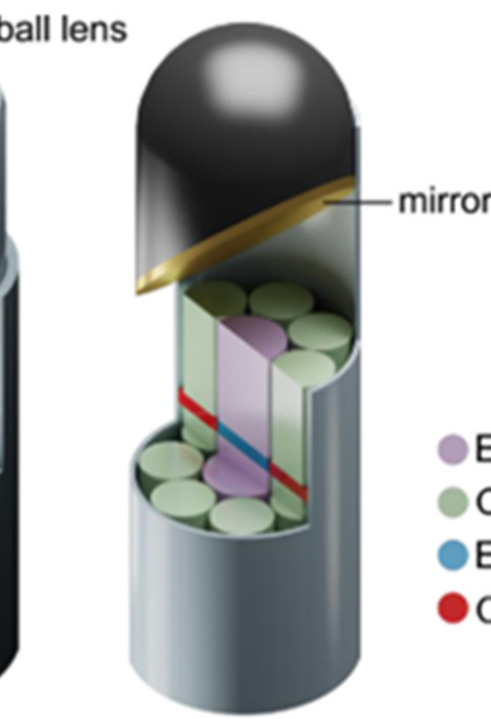

(c)

Figure 4. Different geometries of fiber-probes used in clinical applications: (a) non-superficial endoscopic probe with one excitation fiber in the center and seven collection fibers arranged around the emitter (b) confocal endoscopic fiber probe with a ball lens (c) fiber probes with mirror (or prisms) [87]. https:/ / doi.org/10.1117/1.JBO.23.7.071210, access on 10 January 2022. PMID: 29956506. Excitation and collection filters are also depicted.

Challenges of fiber probe's use pertain to the intense resemblance between the excitation laser light and the collection of the scattered light by the different tissue's anatomical regions [88]. Some of the problems arise due to the background Raman and fluorescence signals created by the fiber's materials and due to the intrinsic fluorescence signal (autofluorescence) of the tissue [54,89]. The separation between the collection and the excitation pathways is still a valid issue for Raman tissue measurements. The background Raman and fluorescence signals created inside the fiber require the separation between the collection and excitation pathway [27]. This generates a challenge regarding the minimum size of such devices. Nijssen et al. attempted to overcome this difficulty by detecting the high wavenumber region from 2500 to $3800 \mathrm{~cm}^{-1}$ (near-infrared region) of the Raman spectrum [47]. That way, the same silica-based fiber optic probe could both guide laser light to the tissue and simultaneously collect scattered light. At the same time, low overlap was achieved with the generated parasitic signals (Rayleigh scattering and Raman from the probe) [47] offering that way a perspective towards the miniaturization of such systems.

Moreover, the development of Raman instrumentation regarding in vivo and ex vivo applications is mainly focusing on the overcoming of issues such as: the speed of measurement, the instrumentation cost, and the background interference due to the different types of tissue. Advanced focal-plane detectors, volume-phase holographic gratings, stabilized diode lasers, and imaging polychromators are building a new perspective towards robust Raman instrumentation $[90,91]$ which achieves high quantum efficiency, simultaneous spectral integration from the high spectral and lateral range and low background noise [90,91]. Therefore, the traditional limitations of low sensitivity and poor detection capability that Raman spectroscopy systems used to present are now dropping drastically [92]. New 
innovative techniques allow infrared and near infrared detection while cutting edge technologies promise system architectures with single photon detection capabilities and hybrid imaging technologies $[91,93,94]$. The development of an in vertical-external-cavity surfaceemitting semiconducting laser presents a large gain area and transverse mode control of the extended cavity, and hence accomplishes a combination of high continuous wave output power and a near diffraction limited beam [93]. Furthermore, semiconductor lasers present the advantages of easy array fabrications and low cost of production [95].

\subsection{Raman Systems for Guided Surgery}

According to current practice, the primary treatment for solid tumors is surgical removal [96-99]. Adequate surgical margins, vital for disease control, are selected for the resection of the entirety of the cancerous tissue. Of vital importance is the preservation of all healthy structures, in cases where the anatomical regions allow it. However, the surgical resection techniques that are currently used are based on subjective methods, such as visual inspection or palpation to verify the exact margins between malignant and normal tissue [96-99]. This may lead to partial removal of the malignancies and consequently to the occurrence of residual tumors, strongly correlated with poor survival rates [96-99]. In addition to that, additional surgeries, or adjuvant therapies such as radiation therapy or chemotherapy may be required. Studies indicate that the five-year survival rate decreases drastically when a solid tumor is not dissected to its entirety [23,96-99]. Portable Raman systems have been implemented into the clinical environment of oncological surgeries presenting excellent assets such as the ability to offer representative sampling towards correct pathological diagnosis and accurate assistance in the definition of resection margins during surgery. As can be depicted in Figure 5, the objectivity of Raman spectroscopy as an imaging technique collaborated with the data analysis and classification capabilities of Machine Learning techniques could constitute a valuable intraoperative guidance tool.

An intraoperative Raman system that directly measures brain tissue in patients has proven to distinguish dense and low-density cancer infiltration from benign brain tissue with a sensitivity of $93 \%$ and a specificity of $91 \%$ [100,101]. More precisely, the experimental setup was pertaining to a hand-held optic Raman probe and a $785 \mathrm{~nm}$ NIR Laser [101]. The research team exploited the boosted trees supervised machine learning algorithm to process their data and eventually differentiate the spectrum among cancerous and healthy brain tissue [101]. In another study, a real-time Raman intraoperative system was used during breast cancer surgery for the assessment of freshly resected specimens [102]. A total of 220 Raman spectra were collected with the aid of an 830-nm-diode laser focused on a Raman optical fiber probe [102]. This study has demonstrated that Raman spectroscopy could discriminate cancerous tissue from normal breast tissue with a sensitivity of $83 \%$ and a specificity of $93 \%$ [102].

A handheld contact Raman spectroscopy probe was used for real-time identification of brain cancer during surgery. Jermyn et al. obtained very fast and high-quality pure Raman signals from $0.5 \mathrm{~mm}$ tissue areas with sampling depth up to $1 \mathrm{~mm}$ during the tumor resection [66] by using micrometer-scale filters that were placed directly at the tip of the optical fibers [66]. A portable clinical fiber probe system in combination with a classification AI algorithm with the ability to differentiate healthy breast tissue from cancerous tissue was utilized by Barman et al. as a guidance tool for mastectomy procedures. The recorded specificity was $100 \%$ with sensitivity of $62.5 \%$ [33]. The differentiation among normal, breast cancer, fibroadenoma, and fibrocystic change was achieved with accuracy of $82.2 \%$ [33]. 


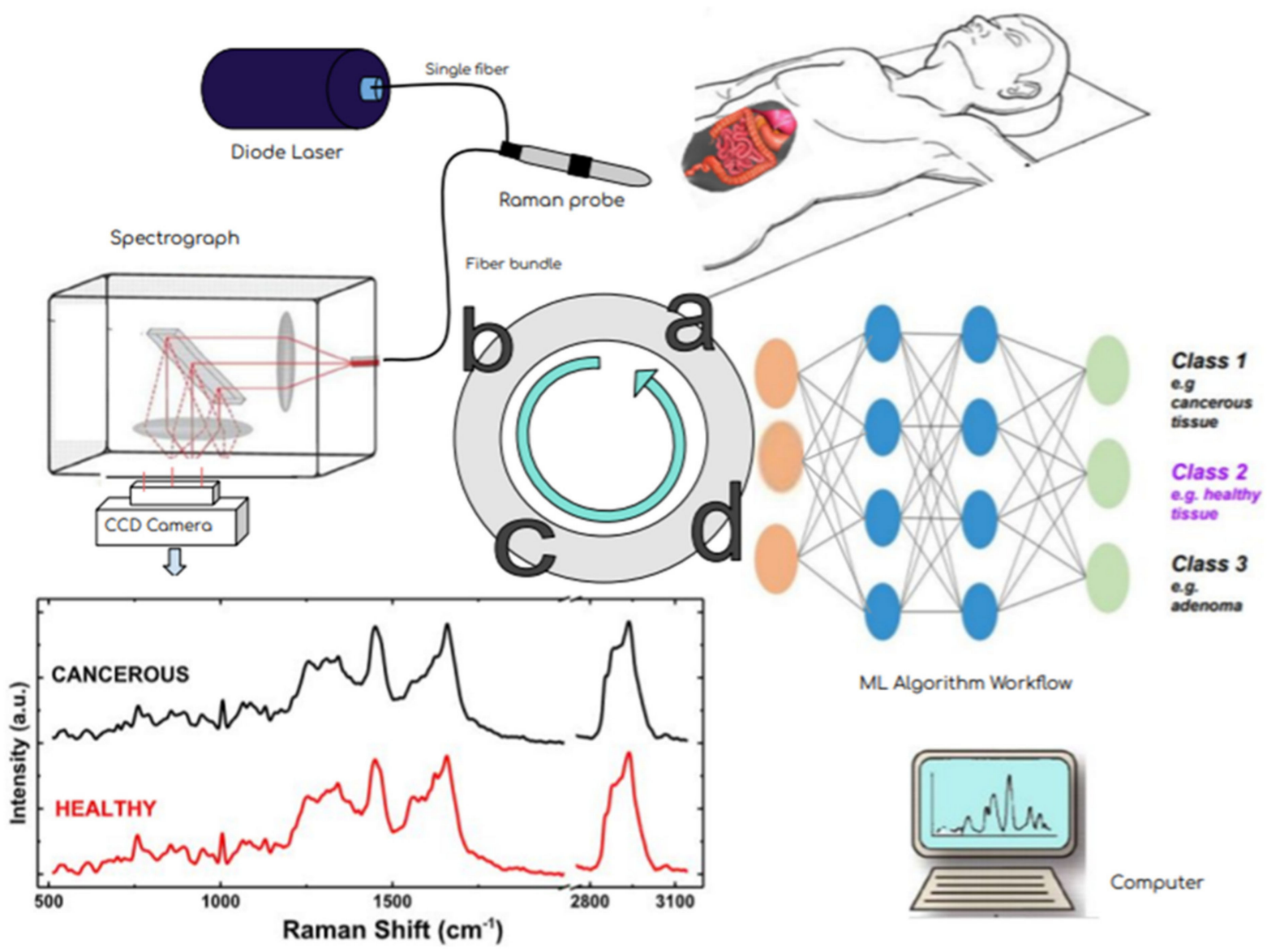

Figure 5. Effectiveness of oncologic surgery depends on precisely distinguishing healthy from malignant tissue during the operation. This flow diagram shows the steps of RS- based diagnosis from the patiant examination (a) via the multicomponent instrumentation (laser excitation-Raman probe-scattered light dispersion and detection) (b) in order to acquire the Raman spectra (schematic, not real data) in (c) and towards their analysis and classification via mashine learning techniques (d). A simple multi-layer perceptron neural network architecture is presented. In fact, the input layer is a data matrix with intensity values from different observations at various Raman frequencies. This combined methodology potentially has the ability to accurately differentiate benign from malignant tissue in real time and eventually improve the surgical outcome.

In order to reduce the time measurement of whole tissue sections in skin cancer, Kong et al. developed the approach of using auto-fluorescence images at excitation wavelengths of $377 \mathrm{~nm}$ and $292 \mathrm{~nm}$ in combination with Raman spectroscopy [42]. Since these wavelengths are the corresponding excited peaks of tryptophan and collagen, they managed to differentiate normal dermis (characterized by high collagen expression) to cancerous segments [42]. This method recorded measurements with specificity of $94 \%$ and sensitivity of 95\% [42]. Short et al. conducted a study using Raman spectroscopy on ex vivo colon tissue from 18 patients, measuring both the fingerprint and high-wavenumber spectral regions [77]. The results indicated that, using the high-wavenumber region, the nonmalignant and the malignant groups could be classified correctly with a specificity of $89 \%$ [77]. The authors referred that the high-wavenumber region could be used in vivo to improve the identification of neoplastic lesions. In the domain of colorectal cancer, Bergholt et al. using an endoscopic multi-fiber Raman probe measured both the fingerprint and high-wavenumber spectral regions of 50 patients in vivo [55]. The team attempted to differentiate Adenomatous polyps from hyperplastic polyps with a specificity of $83 \%$ and a sensitivity of 91\% [55]. Table 1 presents an overview of in vivo Raman measurements for clinical applications that have been attempted for a variety of cancer types. 
Table 1. Clinical Raman applications for diagnosis and surgery guidance.

\begin{tabular}{|c|c|c|c|c|}
\hline $\begin{array}{l}\text { Cancer } \\
\text { Type }\end{array}$ & Current Practice (CP) & Accuracy (CP) & Raman Applications (RA) & Accuracy (RA) \\
\hline \multirow{3}{*}{ Breast } & $\begin{array}{c}\text { Diagnosis } \\
\text { Screening mammography [102] }\end{array}$ & $\begin{array}{l}{ }^{*} \mathrm{~s}: 72 \% \\
{ }^{*} \mathrm{sp}: 47 \% \\
{[102]}\end{array}$ & $\begin{array}{l}\text { early diagnosis } \\
{ }^{*} \text { RS tool for microcalcifications detection in breast tissue [103] }\end{array}$ & $\begin{array}{l}\text { *ppv: } 97 \% \\
{[103]}\end{array}$ \\
\hline & $\begin{array}{l}\text { Histopathological diagnosis: } \\
\text { 1. Fine-needle aspiration cytology [104] }\end{array}$ & $\begin{array}{l}\text { s: } 82-99.7 \% \\
\quad[104]\end{array}$ & \multirow{2}{*}{$\begin{array}{l}\text { surgery guidance } \\
* \text { RS guided tool for mastectomy [33] }\end{array}$} & $\begin{array}{l}\text { s: } 62.5 \% \\
\text { sp: } 100 \%\end{array}$ \\
\hline & 2. Biopsy [105] & $\begin{array}{l}\text { s: } 90.1-93 \% \\
\quad[104]\end{array}$ & & *atd: $82.2 \%$ \\
\hline \multirow{7}{*}{ Skin } & \multirow{2}{*}{$\begin{array}{c}\text { Diagnosis } \\
\text { Visual inspection of morphologic } \\
\text { characteristics with a dermoscope [106] }\end{array}$} & \multirow{2}{*}{$\begin{array}{c}\text { s: } 68-96 \% \\
\text { [107] } \\
\text { *fpsl: } 30 \% \\
{[108]} \\
\text { ppv: } 7-23 \% \\
{[109]}\end{array}$} & $\begin{array}{l}\text { early diagnosis } \\
\text { Single fiber *Rp (in vivo): } \\
\text { 1. Differentiation of malignant/benign lesions [110] }\end{array}$ & $\begin{array}{l}\text { s: } 91 \% \\
\text { sp: } 75 \% \\
{[110]}\end{array}$ \\
\hline & & & 2. Distinguish of malignant melanoma/pigmented benign lesions [110]. & $\begin{array}{l}\text { s: } 97 \% \\
\text { sp: } 78 \% \\
{[110]}\end{array}$ \\
\hline & & & 3. Malignant/pre-malignant lesions separation from benign skin [110]. & $\begin{array}{l}\text { s: } 90 \% \\
\text { sp: } 64 \% \\
{[110]}\end{array}$ \\
\hline & & & Portable R. system with handheld probe for non-melanoma skin/cancerous tissue [111]. & $\begin{array}{l}\text { s: } 100 \% \\
\text { sp: } 91 \% \\
* \text { ca: } 95 \% \\
\text { [111] }\end{array}$ \\
\hline & & & Multi-fiber R.p. (in vivo) for lesions clinically suspected of being skin cancer [112]. & $\begin{array}{l}\text { s: } 52 \% \\
\text { sp: } 67 \% \\
{[112]}\end{array}$ \\
\hline & & & RS with auto-fluorescence for melanoma and BCC diagnosis $[34,113]$. & $\begin{array}{l}\text { *a: } 97.3 \% \\
{[34,113]}\end{array}$ \\
\hline & & & $\begin{array}{l}\text { Surgery guidance } \\
\text { RS (with auto-fluorescence) for intraoperative detection of BCC in skin [42]. }\end{array}$ & $\begin{array}{l}\text { s: } 95 \% \\
\text { sp: } 94 \% \\
\text { a: } 85 \% \\
{[42,114]}\end{array}$ \\
\hline
\end{tabular}


Table 1. Cont.

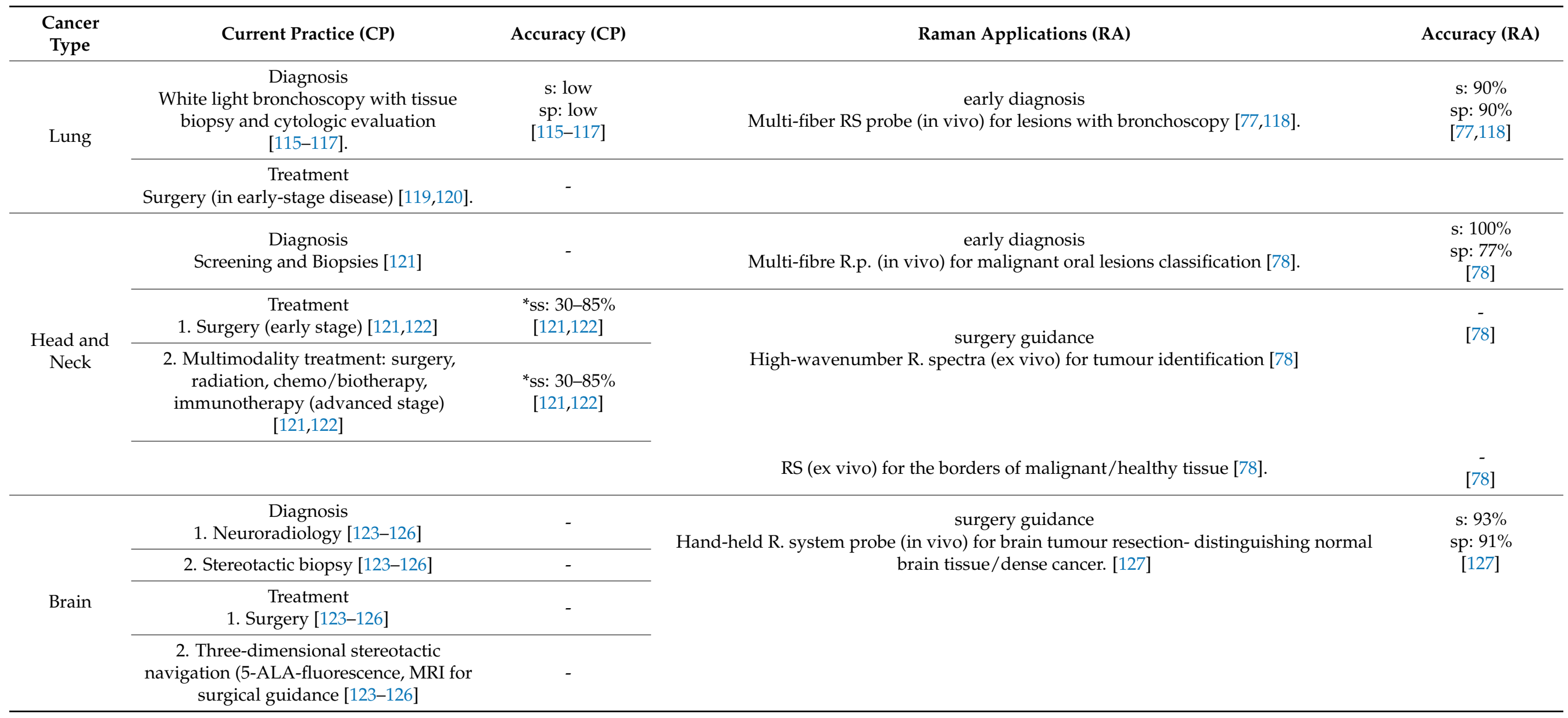


Table 1. Cont.

\begin{tabular}{|c|c|c|c|c|}
\hline $\begin{array}{l}\text { Cancer } \\
\text { Type }\end{array}$ & Current Practice (CP) & Accuracy (CP) & Raman Applications (RA) & Accuracy (RA) \\
\hline \multirow{3}{*}{ Colorectal } & \multirow{2}{*}{$\begin{array}{c}\text { Diagnosis } \\
\text { Screening by colonoscopy [128]. }\end{array}$} & $\begin{array}{l}\text { CRS } \\
{ }^{*} \mathrm{~m} . \mathrm{r}: 2-6 \% \\
{[129,130]}\end{array}$ & \multirow{2}{*}{$\begin{array}{c}\text { early diagnosis } \\
\text { RS (ex vivo) on colon tissue for non malignant/malignant group classification [131]. }\end{array}$} & \multirow{2}{*}{$\begin{array}{l}\text { sp: } 89 \% \\
\text { [131] }\end{array}$} \\
\hline & & $\begin{array}{l}\text { adenomas } \\
\text { *m.r: } 20-26 \% \\
{[129,130]}\end{array}$ & & \\
\hline & $\begin{array}{c}\text { Treatment } \\
\text { Surgery for localized colon cancer } \\
{[132-134]}\end{array}$ & - & $\begin{array}{l}\text { Endoscopic multi-fibre R.p. (in vivo) for the separation of adenomatous } \\
\text { polyps/hyperplastic polyps [135]. }\end{array}$ & $\begin{array}{l}\text { s: } 91 \% \\
\text { sp: } 83 \% \\
{[135]}\end{array}$ \\
\hline \multirow{3}{*}{ Cervical } & $\begin{array}{c}\text { Diagnosis } \\
\text { Screening by cervical cytology (test PAP) } \\
{[136-138]}\end{array}$ & $\begin{array}{l}\text { s: }<50 \% \\
\text { sp: } 95-98 \% \\
{[136-138]}\end{array}$ & $\begin{array}{c}\text { early diagnosis } \\
\text { High-wavenumber ball-lens fiber-optic RS probe (in vivo) for cervical pre-cancer diagnosis } \\
\text { [139]. }\end{array}$ & $\begin{array}{l}\text { s: } 94 \% \\
\text { sp: } 98 \% \\
{[139]}\end{array}$ \\
\hline & $\begin{array}{l}\text { histopathology (colposcopy guided } \\
\text { biopsy) [136-138] }\end{array}$ & $\begin{array}{c}\text { s: } 92 \% \\
\text { sp: } 67 \% \\
{[136-138]}\end{array}$ & Portable fiber-optic R.p. for colposcopy-guided biopsy to investigate dysplasia [140]. & $\begin{array}{l}\text { s: } 86 \% \\
\text { sp: } 97 \% \\
\text { ca: } 88 \% \\
{[140]}\end{array}$ \\
\hline & $\begin{array}{c}\text { Treatment } \\
\text { 1. surgery (small tumours) } \\
\text { 2. chemoradiation (higher stages) } \\
{[141,142]}\end{array}$ & - & & \\
\hline \multirow{2}{*}{ Prostate } & $\begin{array}{l}\text { Diagnosis } \\
\text { 1. transrectal ultrasound } \\
\text { 2. guided prostatic biopsy [143] }\end{array}$ & - & $\begin{array}{l}\text { Raman applications in real clinical area present difficulties due to limitations in research } \\
\qquad[86,144-146]\end{array}$ & \\
\hline & $\begin{array}{l}\text { Treatment } \\
\text { 1. radical prostatectomy } \\
\text { 2. radiation therapy [143] }\end{array}$ & - & & \\
\hline
\end{tabular}




\section{Challenges and Future Perspectives}

The main advantages of RS, such as (a) its non-invasive character and compatibility with tissue physiology due to the weak water signal, (b) its suitability for in vivo fiber-optic applications on versatile cancers, and (c) its high specificity with simultaneous chemical analysis of the malignant tissues have been thoroughly described in the previous sections. There are, however, important limitations of the technique which hinder its establishment in the clinical setting. The most prominent constraints are the following: (a) the weak Raman signals which require long acquisition times, (b) the strong autofluorescence background which affects the quality of the acquired spectra hiding the weak Raman features and complicating the analysis, (c) the potential damage of the tissues by laser heating which is a rather complicated effect depending on the laser excitation wavelength and power, as well as the light absorption coefficient of the tissues, and (d) the subtle differences in the spectra which require sophisticated analysis [147]. Nevertheless, technical advancements in current generation Raman spectrometers and integration of machine learning techniques for big data analysis and cancer classification gradually tilt the balance towards the application of $\mathrm{RS}$ as a rapid diagnostic tool in clinical praxis. It is worthwhile to mention that most of the portable Raman spectrometer manufacturers make their own cooperative research in the field and include such applications in their technical notes. Despite the above limitations, Raman Spectroscopy constitutes a very promising technique for in-situ cancer diagnosis. Since the achievement of adequate surgical margins is vital for disease control and survival, an intraoperative guidance tool such as Raman probes will significantly limit the subjective methods which surgical resection techniques are currently based on (such as palpation and visual inspection). However, the effort to reliably assess resection margins in surgical oncology also suffers from constrains inherent in oncological surgery, such as non-standardized practices and the impact of epithelial or other dysplacias at the margins, as well as differences in reporting the status of the surgical margin. With regard to RS applications on excised tissues, the method employed for the retrieval of sections from resection margins or bioptic samples and the issue of postresection tissue shrinkage introduce extra variability. Recent creation of multidisciplinary networks like ClirSpec, Raman4Clinics (EU COST Action BM1401) and EPIC are significantly narrowing the distance among scientists and clinicians [27]. These networks are actively pursuing the standardization of measurements and of the preparation of the samples, the creation of data analysis protocols, and the settlement of a basis for transferability.

\section{Conclusions}

The compelling recent developments of Raman instrumentation, including the new technologies and the reduction of the cost of lasers, holographic gratings, detectors, and Raman probes as well as the entrance of machine learning models in the analysis of the data have contributed towards the overcoming of some of the method's deficiencies. Thus, they have inspired numerous research groups towards the elaboration of Raman based techniques with biomedical orientation. Among them, cancer prognosis and diagnosis is an excellent candidate, promising low invasive, in vivo and real time detection, and accurate molecular characterization. RS can achieve specificities of $45-100 \%$ and sensitivities of $77-100 \%$ in cancer diagnosis and malignancies detections. The objectiveness of RS and the ability to provide biochemical information in combination with the advancement of the Raman probes that can be integrated in endoscopes and provide spectroscopic images of the tissues may be the solution to the fundamental problem of the deficiencies of pre- and intraoperative methods with adequate and clinically relevant specificity and sensitivity. The prospect of adaptation of Raman spectroscopy into the clinical environment could finally provide surgeons with the assurance of the intraoperatively adequate resection margins while it could upgrade patient's surgical outcome and simultaneously minimize the adjuvant therapies needed. 
Author Contributions: Conceptualization, E.P.E. and E.S.; writing-original draft preparation M.A.K., E.S., D.K. and M.K.; writing-review and editing, M.A.K., E.S., A.G.K., Y.S.R., N.A., N.D., I.S. and E.P.E. All authors have read and agreed to the published version of the manuscript.

Funding: This research was funded by the European Regional Development Fund of the European Union and Greek national funds through the Operational Program Competitiveness, Entrepreneurship and Innovation, under the call RESEARCH-CREATE-INNOVATE (project code: T2EDK-01223).

Acknowledgments: This research has been co-financed by the European Regional Development Fund of the European Union and Greek national funds through the Operational Program Competitiveness, Entrepreneurship and Innovation, under the call RESEARCH-CREATE-INNOVATE (project code: T2EDK-01223). Title: Development of advanced portable biophotonic system for the personalized spectroscopic discrimination of cancer margins/tissues, Acronym: BIOPHASMA). The authors would like to thank M. Labropoulou and A. Tsaroucha A. for their constructive comments on the manuscript.

Conflicts of Interest: There is no conflict of interest.

\section{References}

1. Global Initiative for Cancer Registry Development. Available online: https:// gicr.iarc.fr/about-the-gicr/the-value-of-cancerdata / (accessed on 5 February 2021).

2. Lyon: International Agency for Research on Cancer. Global Initiative for Cancer Registry Development. Available online: https:/ / gco.iarc.fr/today (accessed on 5 February 2021).

3. Global Health Data Exchange. Available online: http://ghdx.healthdata.org/gbd-results-tool (accessed on 5 February 2021).

4. Martel, C.; Georges, D.; Bray, F.; Ferlay, J.; Clifford, G.M. Global burden of cancer attributable to infections in 2018: A worldwide incidence analysis. Lancet Glob. Health 2020, 8, 180-190. [CrossRef]

5. Wild, C.P.; Weiderpass, E.; Stewart, B.W. World Cancer Report: Cancer Research for Cancer Prevention; IARC Publications: Lyon, France, 2020.

6. World Health Organization. Available online: https://www.who.int/publications/i/item/ncd-ccs-2019 (accessed on 5 March 2021).

7. Geboes, K.; Geboes, K.; Jouret-Mourin, A. Endoscopy and Histopathology. In Endoscopy; IntechOpen: London, UK, 2013; Volume 1, pp. 3-32.

8. Bokhorst, L.P.; Zhu, X.; Bul, M.; Bangma, C.H.; Schröder, F.H.; Roobol, M.J. Positive predictive value of prostate biopsy indicated by prostate-specific-antigen-based prostate cancer screening: Trends over time in a European randomized trial. BJU Int. 2012, 110, 1654. [CrossRef] [PubMed]

9. Rominger, M.; Wisgickl, C.; Timmesfeld, N. Breast microcalcifications as type descriptors to stratify risk of malignancy: A systematic review and meta-analysis of 10665 cases with special focus on round/punctate microcalcifications. Rofo 2012, 184, 1144-1152. [CrossRef]

10. McWilliams, A.; Tammemagi, M.C.; Mayo, J.R.; Roberts, H.; Liu, G.; Soghrati, K.; Yasufuku, K.; Martel, S.; Laberge, F.; Gingras, M.; et al. Probability of cancer in pulmonary noduls detected on first screening CT. N. Engl. J. Med. 2013, 369, 910-919. [CrossRef]

11. Carli, P.; Mannone, F.; De Giorgi, V.; Nardini, P.; Chiarugi, A.; Giannoti, B. The problem of false-positive diagnosis in melanoma screening: The impact of dermoscopy. Melanoma Res. 2003, 13, 179-182. [CrossRef] [PubMed]

12. Gambhir, S.S. Molecular imaging of cancer with positron emission tomography. Nat. Rev. Cancer 2002, 2, 683-693. [CrossRef]

13. Khalil, M.M.; Tremoleda, J.L.; Bayomy, T.B.; Gsell, W. Molecular SPECT Imaging: An Overview. Int. J. Mol. Imaging 2011, 2011, 1-15. [CrossRef] [PubMed]

14. Power, S.P.; Moloney, F.; Twomey, M.; James, K.; O'Connor, O.J.; Maher, M.M. Computed tomography and patient risk: Facts, perceptions and uncertainties. World J. Radiol. 2016, 8, 902-915. [CrossRef] [PubMed]

15. Kuo, W.-C.; Kim, J.; Shemonski, N.D.; Chaney, E.J.; Spillman, D.R.; Boppart, A.B. Real-time three-dimensional optical coherence tomography image-guided core-needle biopsy system. Biomed. Opt. Express 2012, 3, 1149-2012. [CrossRef]

16. Song, L.-M.W.K.; Banerjee, S.; Desilets, D.; Diehl, D.L.; Farraye, F.A.; Kaul, V.; Kethu, S.R.; Kwon, R.S.; Mamula, P.; Pedrosa, M.C.; et al. Autofluorescence imaging. Gastrointest. Endosc. 2011, 73, 647-650. [CrossRef]

17. Shin, D.; Vigneswaran, N.; Gillenwater, A.; Richards-Kortum, R. Advances in fluorescence imaging techniques to detect oral cancer and its precursors. Future Oncol. 2010, 6, 1143-1154. [CrossRef] [PubMed]

18. Haris, M.; Yadav, S.K.; Rizwan, A.; Singh, A.; Wang, E.; Hariharan, H.; Reddy, R.; Marincola, F.M. Molecular magnetic resonance imaging in cancer. J. Transl. Med. 2015, 13, 313. [CrossRef] [PubMed]

19. Keren, S.; Zavaleta, C.; Cheng, Z.; de la Zerda, A.; Gheysens, O.; Gambhir, S.S. Noninvasive molecular imaging of small living subjects using Raman spectroscopy. Proc. Natl. Acad. Sci. USA 2008, 105, 5844-5849. [CrossRef] [PubMed]

20. Blasberg, R.G. Molecular Imaging and Cancer. Mol. Cancer Ther. 2003, 2, 335.

21. Wang, W.; Zhao, J.; Short, M.; Zeng, H. Real-time in vivo cancer diagnosis using raman spectroscopy. J. Biophotonics 2015, 8, 527-545. [CrossRef] 
22. Nijssen, A.; Koljenović, S.; Schut, T.C.B.; Caspers, P.J.; Puppels, G.J. Towards oncological application of Raman spectroscopy. J. Biophotonics 2009, 2, 29-36. [CrossRef]

23. Kallaway, C.; Almond, L.M.; Barr, H.; Wood, J.; Hutchings, J.; Kendall, C.; Stone, N. Advances in the clinical application of Raman spectroscopy for cancer diagnostics. Photodiagnosis Photodyn. Ther. 2013, 10, 207-219. [CrossRef]

24. Santos, I.P.; Barroso, E.M.; Bakker Schut, T.C.; Caspers, P.J.; van Lanschot, C.G.F.; Choi, D.-H.; van der Kamp, M.F.; Smits, R.W.H.; van Doorn, R.; Verdijk, R.M.; et al. Raman spectroscopy for cancer detection and cancer surgery guidance: Translation to the clinics. Analyst 2017, 142, 3025-3047. [CrossRef]

25. Hanlon, E.B.; Manoharan, R.; Koo, T.W.; Shafer, K.E.; Motz, J.T.; Fitzmaurice, M.; Kramer, J.R.; Itzkan, I.; Dasari, R.R.; Feld, M.S. Prospects for in vivo Raman spectroscopy. Phys. Med. Biol. 2000, 45, R1-R59. [CrossRef]

26. Santos, I.P.; Caspers, P.J.; Schut, T.B.; van Doorn, R.; Koljenović, S.; Puppels, G.J. Implementation of a novel low-noise InGaAs detector enabling rapid near-infrared multichannel Raman spectroscopy of pigmented biological samples. J. Raman Spectrosc. 2015, 46, 652-660. [CrossRef]

27. Wachsmann-Hogiu, S.; Weeks, T.; Huser, T. Chemical analysis in vivo and in vitro by Raman spectroscopy-from single cells to humans. Curr. Opin. Biotechnol. 2009, 20, 63-73. [CrossRef] [PubMed]

28. Krafft, C.; Schie, I.W.; Meyer, T.; Schmitt, M.; Popp, J. Developments in spontaneous and coherent Raman scattering microscopic imaging for biomedical applications. Chem. Soc. Rev. 2016, 45, 1819-1849. [CrossRef] [PubMed]

29. Orringer, D.A.; Pandian, B.; Niknafs, Y.S.; Hollon, T.C.; Boyle, J.; Lewis, S.; Garrard, M.; Hervey-Jumper, S.L.; Garton, H.J.L.; Maher, C.O.; et al. Rapid intraoperative histology of unprocessed surgical specimens via fibre-laser-based stimulated Raman scattering microscopy. Nat. Biomed. Eng. 2017, 1, 27. [CrossRef] [PubMed]

30. Çulha, M. Raman spectroscopy for cancer diagnosis: How far have we come? Bioanalysis 2015, 7, 2813-2824. [CrossRef]

31. Wang, W.; McGregor, H.; Short, M.; Zeng, H. Clinical utility of Raman spectroscopy: Current applications and ongoing developments. Adv. Health Care Technol. 2016, 2, 13-29. [CrossRef]

32. Camp C.H., Jr.; Cicerone, M.T. Chemically sensitive bioimaging with coherent Raman scattering. Nat. Photonics 2015, 9, 295-305. [CrossRef]

33. Barman, I.; Dingari, N.C.; Saha, A.; McGee, S.; Galindo, L.H.; Liu, W.; Plecha, D.; Klein, N.; Dasari, R.R.; Fitzmaurice, M. Application of Raman Spectroscopy to Identify Microcalcifications and Underlying Breast Lesions at Stereotactic Core Needle Biopsy. Cancer Res. 2013, 73, 3206-3215. [CrossRef]

34. Bratchenko, I.A.; Artemyev, D.A.; Myakinin, O.O.; Khristoforova, Y.A.; Moryatov, A.A.; Kozlov, S.V.; Zakharov, V.P. Combined Raman and autofluorescence ex vivo diagnostics of skin cancer in near-infrared and visible regions. J. Biomed. Opt. 2017, 22, 27005. [CrossRef]

35. Kourkoumelis, N.; Balatsoukas, I.; Moulia, V.; Elka, A.; Gaitanis, G.; Bassukas, I. Advances in the in Vivo Raman Spectroscopy of Malignant Skin Tumors Using Portable Instrumentation. Int. J. Mol. Sci. 2015, 16, 14554-14570. [CrossRef]

36. Austin, L.A.; Osseiran, S.; Evans, C.L. Raman technologies in cancer diagnostics. Anal. 2016, 141, 476-503. [CrossRef]

37. Pence, I.; Mahadevan-Jansen, A. Clinical instrumentation and applications of Raman spectroscopy. Chem. Soc. Rev. 2016, 45, 1958-1979. [CrossRef] [PubMed]

38. Shipp, D.W.; Sinjab, F.; Notingher, I. Raman spectroscopy: Techniques and applications in the life sciences. Adv. Opt. Photonics 2017, 9, 315. [CrossRef]

39. Jermyn, M.; Desroches, J.; Aubertin, K.; St-Arnaud, K.; Madore, W.-J.; De Montigny, E.; Guiot, M.-C.; Trudel, D.; Wilson, B.C.; Petrecca, K.; et al. A review of Raman spectroscopy advances with an emphasis on clinical translation challenges in oncology. Phys. Med. 2016, 61, 370-400. [CrossRef]

40. Devpura, S.; Barton, K.N.; Brown, S.L.; Palyvoda, O.; Kalkanis, S.; Naik, V.M.; Siddiqui, F.; Naik, R.; Chetty, I.J. Vision 20/20: The role of Raman spectroscopy in early stage cancer detection and feasibility for application in radiation therapy response assessment. Med. Phys. 2014, 41, 50901. [CrossRef]

41. Duraipandian, S.; Zheng, W.; Ng, J.; Low, J.J.H.; Ilancheran, A.; Huang, Z. In vivo diagnosis of cervical precancer using Raman spectroscopy and genetic algorithm techniques. Analyst 2011, 136, 4328. [CrossRef] [PubMed]

42. Kong, K.; Rowlands, C.J.; Varma, S.; Perkins, W.; Leach, I.H.; Koloydenko, A.A.; Williams, H.C.; Notingher, I. Diagnosis of tumors during tissue-conserving surgery with integrated autofluorescence and Raman scattering microscopy. Proc. Natl. Acad. Sci. USA 2013, 110, 15189-15194. [CrossRef]

43. McGregor, H.C.; Short, M.A.; McWilliams, A.; Shaipanich, T.; Ionescu, D.N.; Zhao, J.; Wang, W.; Chen, G.; Lam, S.; Zeng, H Real-time endoscopic Raman spectroscopy for in vivo early lung cancer detection. J. Biophot. 2017, 10, 98-110. [CrossRef] [PubMed]

44. Qi, D.; Berger, A.J. Chemical concentration measurement in blood serum and urine samples using liquid-core optical fiber Raman spectroscopy. Appl. Opt. 2007, 46, 1726. [CrossRef] [PubMed]

45. Jones, R.R.; Hooper, D.C.; Zhang, L.; Wolverson, D.; Valev, V.K. Raman Techniques: Fundamentals and Frontiers. Nanoscale Res. Lett. 2019, 14, 231. [CrossRef]

46. Woo, M.-A.; Lee, S.-M.; Kim, G.; Baek, J.H.; Noh, M.S.; Kim, J.E.; Park, S.J.; Minai-Tehrani, A.; Park, S.-C.; Seo, Y.T.; et al. Multiplex Immunoassay Using Fluorescent-Surface Enhanced Raman Spectroscopic Dots for the Detection of Bronchioalveolar Stem Cells in Murine Lung. Anal. Chem. 2009, 81, 1008-1015. [CrossRef] 
47. Nijssen, A.; Maquelin, K.; Santos, L.F.; Caspers, P.J.; Bakker Schut, T.C.; den Hollander, J.C.; Neumann, M.H.A.; Puppels, G.J. Discriminating basal cell carcinoma from perilesional skin using high wave-number Raman spectroscopy. J. Biomed. Opt. 2007, 12, 34004. [CrossRef] [PubMed]

48. Schwartzberg, A.M.; Oshiro, T.Y.; Zhang, J.Z.; Huser, T.; Talley, C.E. Improving Nanoprobes Using Surface-Enhanced Raman Scattering from 30-nm Hollow Gold Particles. Anal. Chem. 2006, 78, 4732-4736. [CrossRef] [PubMed]

49. Qian, X.; Peng, X.-H.; Ansari, D.O.; Yin-Goen, Q.; Chen, G.Z.; Shin, D.M.; Yang, L.; Young, A.N.; Wang, M.D.; Nie, S. In vivo tumor targeting and spectroscopic detection with surface-enhanced Raman nanoparticle tags. Nat. Biotechnol. 2008, 26, 83-90. [CrossRef] [PubMed]

50. Kim, J.H.; Kim, J.S.; Choi, H.; Lee, S.M.; Jun, B.H.; Yu, K.N.; Kuk, E.; Kim, Y.K.; Jeong, D.H.; Cho, M.H.; et al. Nanoparticle Probes with Surface Enhanced Raman Spectroscopic Tags for Cellular Cancer Targeting. Anal. Chem. 2006, 78, 6967-6973. [CrossRef]

51. Wang, H.; Huff, T.B.; Cheng, J.-X. Coherent anti-Stokes Raman scattering imaging with a laser source delivered by a photonic crystal fiber. Opt. Lett. 2006, 31, 1417-1419. [CrossRef]

52. Okuno, M.; Kano, H.; Leproux, P.; Couderc, V.; Hamaguchi, H. Ultrabroadband multiplex CARS microspectroscopy and imaging using a subnanosecond supercontinuum light source in the deep near infrared. Opt. Lett. 2008, 33, 923-925. [CrossRef]

53. Potma, E.O.; Evans, C.L.; Xie, X.S. Heterodyne coherent anti-Stokes Raman scattering (CARS) imaging. Opt. Lett. 2006, 31, 241-243. [CrossRef]

54. Ly, S.; McNerney, G.; Fore, S.; Chan, J.; Huser, T. Time-gated single photon counting enables separation of CARS microscopy data from multiphoton-excited tissue autofluorescence. Opt. Express 2007, 15, 16839-16851. [CrossRef]

55. Bergholt, M.S.; Lin, K.; Wang, J.; Zheng, W.; Xu, H.; Huang, Q.; Ren, J.L.; Ho, K.Y.; Teh, M.; Srivastava, S.; et al. Simultaneous fingerprint and high-wavenumber fiber-optic Raman spectroscopy enhances real-time in vivo diagnosis of adenomatous polyps during colonoscopy. J. Biophotonics 2015, 9, 333-342. [CrossRef]

56. Brozek-Pluska, B.; Musial, J.; Kordek, R.; Abramczyk, H. Analysis of Human Colon by Raman Spectroscopy and ImagingElucidation of Biochemical Changes in Carcinogenesis. Int. J. Mol. Sci. 2019, 20, 3398. [CrossRef]

57. He, H.; Yan, S.; Lyu, D.; Xu, M.; Ye, R.; Zheng, P.; Lu, X.; Wang, L.; Ren, B. Deep Learning for Biospectroscopy and Biospectral Imaging: State-of-the-Art and Perspectives. Anal. Chem. 2021, 93, 3653-3665. [CrossRef] [PubMed]

58. Ian, G.; Yoshua, B.; Aaron, C. Deep Learning; MIT Press: Cambridge, MA, USA, 2016.

59. Hinton, G.; Deng, L.; Yu, D.; Dahl, E.G.; Mohamed, A.; Jaitly, N.; Senior, A.; Vanhoucke, V.; Nguyen, P.; Sainath, N.T.; et al. Deep Neural Networks for Acoustic Modeling in Speech Recognition: The Shared Views of Four Research Groups. IEEE Signal Process. Mag. 2012, 29, 82-97. [CrossRef]

60. Sainath, T.N.; Mohamed, A.; Kingsbury, B.; Ramabhadran, B. Deep convolutional neural networks for LVCSR. In Proceedings of the 2013 IEEE International Conference on Acoustics, Speech and Signal Processing, Vancouver, BC, Canada, 26 May 2013; pp. 8614-8618. [CrossRef]

61. Mor-Yosef, S.; Samueloff, A.; Modan, B.; Navot, D.; Schenker, J.G. Ranking the risk factors for cesarean: Logistic regression analysis of a nationwide study. Obstet. Gynecol. 1990, 75, 944-947. [PubMed]

62. Krizhevsky, A.; Sutskever, I.; Hinton, G.E. ImageNet classification with deep convolutional neural networks. Commun. ACM 2017, 60, 84-90. [CrossRef]

63. Farabet, C.; Couprie, C.; Najman, L.; LeCun, Y. Learning Hierarchical Features for Scene Labeling. IEEE Trans. Pattern Anal. Mach. Intell. 2012, 35, 1915-1929. [CrossRef] [PubMed]

64. Cornell University. Available online: http:/ /arxiv.org/abs/1409.4842 (accessed on 17 September 2014).

65. Tolstik, T.; Marquardt, C.; Matthäus, C.; Bergner, N.; Bielecki, C.; Krafft, C.; Stallmach, A.; Popp, J. Discrimination and classification of liver cancer cells and proliferation states by Raman spectroscopic imaging. Analyst 2014, 139, 6036-6043. [CrossRef] [PubMed]

66. Jermyn, M.; Mok, K.; Mercier, J.; Desroches, J.; Pichette, J.; Saint-Arnaud, K.; Bernstein, L.; Guiot, M.C.; Petrecca, K.; Leblond, F. Intraoperative brain cancer detection with Raman spectroscopy in humans. Sci. Transl. Med. 2015, 7, 274ra19. [CrossRef] [PubMed]

67. Shu, C.; Yan, H.; Lin, K.; Lim, C.M.; Zheng, W.; Feng, J.; Huang, Z. Biomedical Vibrational Spectroscopy 2020: Advances in Research and Industry; SPIE: San Francisco, CA, USA, 2020; Volume 11236.

68. Chen, H.; Li, X.; Broderick, N.; Liu, Y.; Zhou, Y.; Han, J.; Xu, W.J. Identification and characterization of bladder cancer by low-resolution fiber-optic Raman spectroscopy. J. Biophoton. 2018, 11, e201800016. [CrossRef]

69. Kourou, K.; Exarchos, T.P.; Exarchos, K.P.; Karamouzis, V.M.; Fotiadis, D.I. Machine learning applications in cancer prognosis and prediction. Comput. Struct. Biotechnol. J. 2015, 13, 8-17. [CrossRef]

70. Li, X.; Yang, T.; Li, S.; Wang, D.; Song, Y.; Zhang, S. Raman spectroscopy combined with principal component analysis and k nearest neighbour analysis for non-invasive detection of colon cancer. Laser Phys. 2016, 26, 35702. [CrossRef]

71. Kothari, R.; Jones, V.; Mena, D.; Bermúdez Reyes, V.; Shon, Y.; Smith, J.P.; Schmolze, D.; Cha, P.D.; Lai, L.; Fong, Y.; et al. Raman spectroscopy and artificial intelligence to predict the Bayesian probability of breast cancer. Sci. Rep. 2021, 11, 6482. [CrossRef] [PubMed]

72. Li, Q.; Li, W.; Zhang, J.; Xu, Z. An improved k-nearest neighbour method to diagnose breast cancer. Analyst 2018, 143, $2807-2811$. [CrossRef]

73. Li, S.; Chen, G.; Zhang, Y.; Guo, Z.; Liu, Z.; Xu, J.; Li, X.; Lin, L. Identification and characterization of colorectal cancer using Raman spectroscopy and feature selection techniques. Opt. Express 2014, 22, 25895-25908. [CrossRef] [PubMed] 
74. Yu, M.; Yan, H.; Xia, J.; Zhu, L.; Zhang, T.; Zhu, Z.; Lou, X.; Sun, G.; Dong, M. Deep convolutional neural networks for tongue squamous cell carcinoma classification using Raman spectroscopy. Photodiagnosis Photodyn. Ther. 2019, 26, 430-435. [CrossRef] [PubMed]

75. Short, M.A.; Lam, S.; McWilliams, A.M.; Ionescu, D.N.; Zeng, H. Using Laser Raman Spectroscopy to Reduce False Positives of Autofluorescence Bronchoscopies: A Pilot Study. J. Thorac. Oncol. 2011, 6, 1206-1214. [CrossRef]

76. Krishna, H.; Majumder, S.K.; Chaturvedi, P.; Sidramesh, M.; Gupta, P.K. In vivo Raman spectroscopy for detection of oral neoplasia: A pilot clinical study. J. Biophotonics 2014, 7, 690-702. [CrossRef]

77. Short, M.A.; Tai, I.T.; Owen, D.; Zeng, H. Using high frequency Raman spectra for colonic neoplasia detection. Opt. Express 2013, 21, 5025-5034. [CrossRef]

78. Kwak, J.; Lee, W.; Kim, J.B.; Bae, S.I.; Jeong, K.H. Fiber-optic plasmonic probe with nanogap-rich Au nanoislands for on-site surface-enhanced Raman spectroscopy using repeated solid-state dewetting. J. Biomed. Opt. 2019, 24, 1-6. [CrossRef]

79. Garai, E.; Sensarn, S.; Zavaleta, C.L.; Loewke, N.O.; Rogalla, S.; Mandella, M.J.; Flet, S.A.; Friedland, S.; Liu, J.T.C.; Contag, C.H.; et al. A Real-Time Clinical Endoscopic System for Intraluminal, Multiplexed Imaging of Surface-Enhanced Raman Scattering Nanoparticles. PLoS ONE 2015, 10, e0123185. [CrossRef]

80. Matousek, P.; Clark, I.P.; Draper, E.R.C.; Morris, M.D.; Goodship, A.E.; Everall, N.; Towrie, M.; Finney, W.F.; Parker, A.W. Subsurface probing in diffusely scattering media using spatially offset Raman spectroscopy. Appl. Spectrosc. 2005, 59, 393-400. [CrossRef]

81. Stone, N.; Kerssens, M.; Lloyd, G.R.; Faulds, K.; Graham, D.; Matousek, P. Surface enhanced spatially offset Raman spectroscopic (SESORS) imaging-The next dimension. Chem. Sci. 2011, 2, 776-780. [CrossRef]

82. Yumin, Z.; Li, L.; Jing, H.Y. Optical penetration of surface-enhanced micro-scale spatial offset Raman spectroscopy in turbid gel and biological tissue. J. Innov. Opt. Health Sci. 2021, 14, 2141001. [CrossRef]

83. Stevens, O.; Petterson, I.E.I.; Day, J.C.C.; Stone, N. Developing fiber optic Raman probes for applications in clinical spectroscopy. Chem. Soc. Rev. 2016, 45, 1919-1934. [CrossRef]

84. Wang, J.; Lin, K.; Zheng, W.; Ho, K.; Teh, M.; Yeoh, K.; Huang, Z. Comparative study of the endoscope-based bevelled and volume fiber-optic Raman probes for optical diagnosis of gastric dysplasia in vivo at endoscopy. Anal. Bioanal. Chem. 2015, 407, 8303-8310. [CrossRef] [PubMed]

85. Duraipandian, C.; Bergholt, M.D.; Zheng, W.; Ho, K.Y.; Teh, M.; Yeoh, K.G.; So, J.B.Y.; Shabbir, A.; Huang, Z. Real-time Raman spectroscopy for in vivo, online gastric cancer diagnosis during clinical endoscopic examination. J. Biomed. Opt. 2012, $17,81418$. [CrossRef] [PubMed]

86. Agenant, M.; Grimbergen, M.; Draga, R.; Marple, E.; Bosch, R.; Van Swol, C. Clinical superficial Raman probe aimed for epithelial tumor detection: Phantom model results. Biomed. Opt. Express 2014, .5, 1203-1216. [CrossRef]

87. Cordero, E.; Latka, I.; Matthäus, C.; Schie, I.; Popp, J. In-vivo Raman spectroscopy: From basics to applications. J. Biomed. Opt. 2018, 23, 1-23. [CrossRef]

88. Latka, I.; Dochow, S.; Krafft, C.; Dietzek, B.; Popp, J. Fiber optic probes for linear and nonlinear Raman applications-Current trends and future development. Laser and Photonics Rev. 2013, 7, 698-731. [CrossRef]

89. Motz, J.T.; Gandhi, S.J.; Scepanovic, O.R.; Haka, A.S.; Kramer, J.R.; Dasari, R.R.; Feld, M.S. Real-time Raman system for in vivo disease diagnosis. J. Biomed. Opt. 2005, 10, 31113. [CrossRef]

90. Chen, K.; Qin, Y.; Zheng, F.; Sun, M.; Shi, D. Diagnosis of colorectal cancer using Raman spectroscopy of laser-trapped single living epithelial cells. Opt. Lett. 2006, 31, 2015-2017. [CrossRef]

91. Denson, S.C.; Pommier, C.J.S.; Denton, M.B. The Impact of Array Detectors on Raman Spectroscopy. J. Chem. Educ. 2007, 84, 67-74. [CrossRef]

92. Sharma, S.K.; Egan, M.J. Raman Spectroscopy, Remote Compositional Analysis; Cambridge University Press: Cambridge, UK, 2019; pp. 120-146. [CrossRef]

93. Okhotnikov, O.G. Semiconductor Disk Lasers: Physics and Technology; WILEY-VCH: Weinheim, Germany, 2010.

94. Pallmann, W.P.; Zaugg, C.A.; Mangold, M.; Wittwer, V.J.; Moench, H.; Gronenborn, S.; Miller, M.; Tilma, B.W.; Südmeyer, T.; Keller, U. Gain characterization and passive modelocking of electrically pumped VECSELs. Opt. Express 2012, 20, 24791. [CrossRef] [PubMed]

95. Yan, Y.; Zheng, Y.; Sun, H.; Duan, J. Review of Issues and Solutions in High-Power Semiconductor Laser Packaging Technology. Front. Phys. 2021, 9, 669591. [CrossRef]

96. Smits, R.W.H.; Koljenović, S.; Hardillo, J.A.; Hove, I.T.; Meeuwis, C.A.; Sewnaik, A.; Dronkers, E.A.; Schut, T.C.B.; Langeveld, T.P.M.; Molenaar, J.; et al. Resection margins in oral cancer surgery: Room for improvement. Head Neck 2016, 38 (Suppl. S1), E2197-E2203. [CrossRef]

97. Binahmed, A.; Nason, R.W.; Abdoh, A.A. The clinical significance of the positive surgical margin in oral cancer. Oral Oncol. 2007, 43, 780-784. [CrossRef]

98. Neuzillet, Y.; Soulie, M.; Larre, S.; Roupret, M.; Defortescu, G.; Murez, T.; Pignot, G.; Descazeaud, A.; Patard, J.J.; Bigot, P.; et al. Positive surgical margins and their locations in specimens are adverse prognosis features after radical cystectomy in non-metastatic carcinoma invading bladder muscle: Results from a nationwide case-control study. BJU Int. 2013, 111, 1253-1260. [CrossRef] 
99. Wong, J.M.; Panchmatia, J.R.; Ziewacz, J.E.; Bader, A.M.; Dunn, I.F.; Laws, E.R.; Gawande, A.A. Patterns in neurosurgical adverse events: Intracranial neoplasm surgery. Neurosurg. Focus 2012, 33, E16. [CrossRef]

100. Auner, G.W.; Koya, S.K.; Huang, C.; Broadbent, B.; Trexler, M.; Auner, Z.; Elias, A.; Curtin Mehne, K.; Brusatori, M.A. Applications of Raman spectroscopy in cancer diagnosis. Cancer Metastasis Rev. 2018, 37, 691-717. [CrossRef]

101. Haka, A.S.; Volynskaya, Z.; Gardecki, J.A.; Nazemi, J.; Shenk, R.; Wang, N.; Dasari, R.R.; Fitzmaurice, M.; Feld, M.S. Diagnosing breast cancer using Raman spectroscopy: Prospective analysis. J. Biomed. Opt. 2009, 14, 54023. [CrossRef]

102. World Health Organization. Available online: http:/ / globocan.iarc.fr (accessed on 22 March 2017).

103. Saha, A.; Barman, I.; Dingari, N.C.; McGee, S.; Volynskaya, Z.; Galindo, L.H.; Liu, W.; Plecha, D.; Klein, N.; Dasari, R.R. Raman spectroscopy: A real-time tool for identifying microcalcifications during stereotactic breast core needle biopsies. Biomed. Opt. Express 2011, 2, 2792-2803. [CrossRef]

104. Wang, M.; He, X.; Chang, Y.; Sun, G.; Thabane, L. A sensitivity and specificity comparison of fine needle aspiration cytology and core needle biopsy in evaluation of suspicious breast lesions: A systematic review and meta-analysis. The Breast 2017, 31, 157-166. [CrossRef]

105. Johnson, J.M.; Dalton, R.R.; Wester, S.M.; Landercasper, J.; Lambert, P.J. Histological Correlation of Microcalcifications in Breast Biopsy Specimens. Arch Surg. 1999, 134, 712-716. [CrossRef] [PubMed]

106. Kittler, H.; Pehamberger, H.; Wolff, K.; Binder, M. Diagnostic accuracy of dermoscopy. Lancet Oncol. 2002, 3, 159-165. [CrossRef]

107. Morton, C.A.; Mackie, R.M. Clinical accuracy of the diagnosis of cutaneous malignant melanoma. Br. J. Dermatol. 1998, 138, 283-287. [CrossRef] [PubMed]

108. Van der Rhee, J.I.; Bergman, W.; Kukutsch, N.A. Impact of Dermoscopy on the Management of High-risk Patients from Melanoma Families: A Prospective Study. Acta Derm.-Venereol. 2011, 91, 428-431. [CrossRef] [PubMed]

109. Santos, I.P.; Caspers, P.J.; Bakker Schut, T.C.; Van Doorn, R.; Noordhoek Hegt, V.; Koljenović, S.; Puppels, G.J. Raman Spectroscopic Characterization of Melanoma and Benign Melanocytic Lesions Suspected of Melanoma Using High-Wavenumber Raman Spectroscopy. Anal. Chem. 2016, 88, 7683-7688. [CrossRef] [PubMed]

110. Lui, H.; Zhao, J.; McLean, D.; Zeng, H. Real-time Raman Spectroscopy for In Vivo Skin Cancer Diagnosis. Cancer Res. 2012, 72, 2491-2500. [CrossRef]

111. Schleusener, J.; Gluszczynska, P.; Reble, C.; Gersonde, I.; Helfmann, J.; Fluhr, J.W.; Lademann, J.; Röwert-Huber, J.; Patzelt, A.; Meinke, M.C. In vivo study for the discrimination of cancerous and normal skin using fibre probe-based Raman spectroscopy. Exp. Dermatol. 2015, 24, 767-772. [CrossRef]

112. Bodanese, B.; Silveira, F.L.; Zângaro, R.A.; Pacheco, M.T.; Pasqualucci, C.A.; Silveira, L., Jr. Discrimination of basal cell carcinoma and melanoma from normal skin biopsies in vitro through Raman spectroscopy and principal component analysis. Photomed. Laser Surg. 2012, 30, 381-387. [CrossRef]

113. O’Brien, C.M.; Vargis, E.; Rudin, A.; Slaughter, J.C.; Thomas, G.; Newton, J.M.; Reese, J.; Bennett, K.A.; Mahadevan-Jansen, A. In vivo Raman spectroscopy for biochemical monitoring of the human cervix throughout pregnancy. Am. J. Obs. Gynecol. 2018, 218, 528.e1-528.e18. [CrossRef]

114. Lieber, C.A.; Majumder, S.K.; Ellis, D.L.; Billheimer, D.D.; Mahadevan-Jansen, A. In vivo nonmelanoma skin cancer diagnosis using Raman microspectroscopy. Lasers Surg. Med. 2008, 40, 461-467. [CrossRef] [PubMed]

115. Sun, J.; Garfield, D.H.; Lam, B.; Yan, J.; Gu, A.; Shen, J.; Han, B. The Value of Autofluorescence Bronchoscopy Combined with White Light Bronchoscopy Compared with White Light Alone in the Diagnosis of Intraepithelial Neoplasia and Invasive Lung Cancer: A Meta-Analysis. J. Thorac. Oncol. 2011, 6, 1336-1344. [CrossRef]

116. Criner, G.J.; Eberhardt, R.; Fernandez-Bussy, S.; Gompelmann, D.; Maldonado, F.; Patel, N.; Shah, P.L.; Slebos, D.J.; Valipour, A.; Wahidi, M.M.; et al. Interventional Bronchoscopy. Am. J. Respir. Crit. Care Med. 2020, 202, 29-50. [CrossRef]

117. Idowu, M.O.; Powers, C.N. Lung cancer cytology: Potential pitfalls and mimics-A review. Int. J. Clin. Exp. Pathol. 2010, 3, 367-385. [PubMed]

118. Short, M.A.; Lam, S.; McWilliams, A.; Zhao, J.; Lui, H.; Zeng, H. Development and preliminary results of an endoscopic Raman probe for potential in vivo diagnosis of lung cancers. Opt. Lett. 2008, 33, 711-713. [CrossRef]

119. Ginsberg, R.J.; Rubinstein, L.V. Randomized trial of lobectomy versus limited resection for $T_{1}$ No non-small cell lung cancer. Lung Cancer Study Group. Ann. Thorac. Surg. 1995, 60, 615-623. [CrossRef]

120. Blasberg, J.D.; Pass, H.I.; Donington, J.S. Sublobar resection: A movement from the Lung Cancer Study Group. J. Thorac. Oncol. 2010, 5, 1583-1593. [CrossRef]

121. Hoffmannová, J.; Foltán, R.; Vlk, M.; Šipoš, M.; Horká, E.; Pavlíková, G.; Kufa, R.; Bulík, O.; Šedý, J. Hemimandibulectomy and therapeutic neck dissection with radiotherapy in the treatment of oral squamous cell carcinoma involving mandible: A critical review of treatment protocol in the years 1994-2004. Int. J. Oral Maxillofac. Surg. 2010, 39, 561-567. [CrossRef]

122. Aaboubout, Y.; Hove, I.T.; Smits, R.W.H.; Hardillo, J.A.; Puppels, G.J.; Koljenovic, S. Specimen-driven intraoperative assessment of resection margins should be standard of care for oral cancer patients. Oral Dis. 2020, 27, 111-116. [CrossRef]

123. Hanif, F.; Muzaffar, K.; Perveen, K.; Malhi, S.M.; Simjee, S. Glioblastoma Multiforme: A Review of its Epidemiology and Pathogenesis through Clinical Presentation and Treatment. Asian Pac. J. Cancer Prev. APJCP 2017, 18, 3-9.

124. Hollon, T.; Lewis, S.; Freudiger, C.W.; Sunney Xie, X.; Orringer, D.A. Improving the accuracy of brain tumor surgery via Raman-based technology. Neurosurg. Focus 2016, 40, E9. [CrossRef] 
125. Koljenović, S.; Choo-Smith, L.-P.; Bakker Schut, T.C.; Kros, J.M.; Van den Berge, H.J. Puppels, G.J. Discriminating vital tumor from necrotic tissue in human glioblastoma tissue samples by Raman spectroscopy. Lab. Invest. 2002, 82, 1265-1277. [CrossRef] [PubMed]

126. Lu, F.K.; Calligaris, D.; Olubiyi, O.I.; Norton, I.; Yang, W.; Santagata, S.; Xie, X.S.; Golby, A.J.; Agar, N.Y.R. Label-Free Neurosurgical Pathology with Stimulated Raman Imaging. Cancer Res. 2016, 76, 3451-3462. [CrossRef] [PubMed]

127. Desroches, J.; Jermyn, M.; Pinto, M. A new method using Raman spectroscopy for in vivo targeted brain cancer tissue biopsy. Sci. Rep. 2018, 8, 1-10. [CrossRef] [PubMed]

128. Labianca, R.; Merelli, B. Screening and Diagnosis for Colorectal Cancer: Present and Future. Tumori J. 2010, 96, 889-901. [CrossRef]

129. Bressler, B.; Paszat, L.F.; Chen, Z.; Rothwell, D.M.; Vinden, C.; Rabeneck, L. Rates of new or missed colorectal cancers after colonoscopy and their risk factors: A population-based analysis. Gastroenterology 2007, 132, 96-102. [CrossRef]

130. Quintero, E.; Hassan, C.; Senore, C.; Saito, Y. Progress and Challenges in Colorectal Cancer Screening. Gastroenterol. Res. Pract. 2012, 2012, 846985. [CrossRef]

131. Amri, R.; Bordeianou, L.G.; Sylla, P.; Berger, D.L. Association of Radial Margin Positivity with Colon Cancer. JAMA Surg. 2015, 150, 890-898. [CrossRef]

132. Kim, Y.I.; Jeong, S.; Jung, K.O.; Song, M.G.; Lee, C.H.; Chung, S.J.; Park, J.Y.; Cha, M.G.; Lee, S.G.; Jun, B.H.; et al. Simultaneous Detection of EGFR and VEGF in Colorectal Cancer using Fluorescence-Raman Endoscopy. Sci. Rep. 2017, 7, 1035. [CrossRef]

133. Arimoto, J.; Higurashi, T.; Chiba, H.; Misawa, N.; Yoshihara, T.; Kato, T.; Kanoshima, K.; Fuyuki, A.; Ohkubo, H.; Nonaka, T.; et al. Investigation of the Local Recurrence Rate after Colorectal Endoscopic Mucosal Resection: Is Incomplete Polyp Resection Really a Clinically Important Problem? Analysis of the Rationale for the "Resect and Discard" Strategy. Can. J. Gastroenterol. Hepatol. 2019, 2019, 72435151-7. [CrossRef]

134. Lynch, M.L.; Brand, M.I. Preoperative evaluation and oncologic principles of colon cancer surgery. Clin. Colon Rectal Surg. 2005, 18, 163-173. [CrossRef] [PubMed]

135. O'Connell, J.B.; Maggard, M.A.; Ko, C.Y. Colon cancer survival rates with the new American Joint Committee on Cancer sixth edition staging. J. Natl. Cancer Inst. 2004, 96, 1420-1425. [CrossRef] [PubMed]

136. Peirson, L.; Fitzpatrick-Lewis, D.; Ciliska, D.; Warren, R. Screening for cervical cancer: A systematic review and meta-analysis. Syst. Rev. 2013, 2, 35. [CrossRef] [PubMed]

137. Canfell, K.; Barnabas, R.; Patnick, J.; Beral, V. The predicted effect of changes in cervical screening practice in the UK: Results from a modelling study. Br. J. Cancer 2004, 91, 530-536. [CrossRef] [PubMed]

138. Cuzick, J.; Clavel, C.; Petry, K.U.; Meijer, C.J.; Hoyer, H.; Ratnam, S.; Szarewski, A.; Birembaut, P.; Kulasingam, S.; Sasieni, P.; et al. Overview of the European and North American studies on HPV testing in primary cervical cancer screening. Int. J. Cancer 2006, 119, 1095-1101. [CrossRef]

139. Arbyn, M.; Castellsague, X.; de Sanjose, S.; Bruni, L.; Saraiya, M.; Bray, F.; Ferlay, J. Worldwide burden of cervical cancer in 2008. Ann. Oncol. 2011, 22, 2675-2686. [CrossRef]

140. Duraipandian, S.; Zheng, W.; Ng, J.; Low, J.J.H.; Ilancheran, A.; Huang, Z. Non-invasive analysis of hormonal variations and effect of postmenopausal Vagifem treatment on women using in vivo high wavenumber confocal Raman spectroscopy. Anal. Chem. 2012, 84, 5913-5919. [CrossRef]

141. Petignat, P.; Roy, M. Diagnosis and management of cervical cancer. BMJ 2007, 335, 765. [CrossRef]

142. Cornelio, D.B.; Meurer, L.; Schwartsmann, G.; Roesler, R. The gastrin-releasing peptide receptor as a marker of dysplastic alterations in cervical epithelial cells. Oncology 2012, 82, 90-97. [CrossRef]

143. Ruijter, E.; van de Kaa, C.; Miller, G.; Ruiter, D.; Debruyne, F.; Schalken, J. Molecular genetics and epidemiology of prostate carcinoma. Endocr. Rev. 1999, 20, 22-45. [CrossRef]

144. Park, J.J.; Kim, D.K.; Lee, S.; Choi, Y.; Kim, Y.H.; Lee, J.H.; Kim, K.H.; Kim, J.H. Diagnostic accuracy of Raman spectroscopy for prostate cancer: A systematic review and meta-analysis. Transl. Androl. Urol. 2021, 10, 574-583. [CrossRef] [PubMed]

145. Aubertin, K.; Desroches, J.; Jermyn, M.; Trinh, V.Q.; Saad, F.; Trudel, D.; Leblond, F. Combining high wavenumber and fingerprint Raman spectroscopy for the detection of prostate cancer during radical prostatectomy. Biomed. Opt. Express 2018, 9, $4294-4305$. [CrossRef] [PubMed]

146. Kast, R.E.; Tucker, S.C.; Killian, K.; Trexler, M.V.; Honn, K.; Auner, G.W. Emerging technology: Applications of Raman spectroscopy for prostate cancer. Cancer Metastasis 2014, 33, 673-693. [CrossRef] [PubMed]

147. Eberhardt, K.; Stiebing, C.; Matthäus, C.; Schmitt, M.; Popp, J. Advantages and limitations of Raman spectroscopy for molecular diagnostics: An update. Expert Rev. Mol. Diagn. 2015, 15, 773-787. [CrossRef] [PubMed] 